\title{
Milk Fatty Acid Profiles in Different Animal Species: Focus on the Potential Effect of Selected PUFAs on Metabolism and Brain Functions
}

\author{
Maria P. Mollica ${ }^{1,2}$, Giovanna Trinchese ${ }^{1,2}{ }^{D}$, Fabiano Cimmino ${ }^{1}$, Eduardo Penna ${ }^{1}$, Gina Cavaliere ${ }^{1}$, \\ Raffaella Tudisco $^{3}\left(\mathbb{D}\right.$, Nadia Musco ${ }^{3} \mathbb{D}$, Claudia Manca ${ }^{4}\left(\mathbb{D}\right.$, Angela Catapano ${ }^{1,5}$, Marcellino Monda ${ }^{6}$ (D), \\ Paolo Bergamo ${ }^{7, * D}$, Sebastiano Banni ${ }^{4}$, Federico Infascelli ${ }^{3} \mathbb{D}$, Pietro Lombardi ${ }^{3,+}+\mathbb{D}$ and Marianna Crispino ${ }^{1,+}+\mathbb{D}$
}

\section{check for} updates

Citation: Mollica, M.P.; Trinchese, G.; Cimmino, F.; Penna, E.; Cavaliere, G.; Tudisco, R.; Musco, N.; Manca, C.; Catapano, A.; Monda, M.; et al. Milk Fatty Acid Profiles in Different Animal Species: Focus on the Potential Effect of Selected PUFAs on Metabolism and Brain Functions. Nutrients 2021, 13, 1111. https:// doi.org/10.3390/nu13041111

Academic Editor: Michael J. Puglisi

Received: 27 February 2021

Accepted: 24 March 2021

Published: 28 March 2021

Publisher's Note: MDPI stays neutral with regard to jurisdictional claims in published maps and institutional affiliations.

Copyright: (c) 2021 by the authors. Licensee MDPI, Basel, Switzerland. This article is an open access article distributed under the terms and conditions of the Creative Commons Attribution (CC BY) license (https:/ / creativecommons.org/licenses/by/ $4.0 /)$.
1 Department of Biology, University of Naples Federico II, 80126 Naples, Italy; mariapia.mollica@unina.it (M.P.M.); giovanna.trinchese@unina.it (G.T.); fabiano.cimmino@unina.it (F.C.); eduardo.penna@unina.it (E.P.); gina.cavaliere@unina.it (G.C.); angelacatapano@me.com (A.C.); crispino@unina.it (M.C.)

2 BAT Center-Interuniversity Center for Studies on Bioinspired Agro-Environmental Technology, University of Naples 'Federico II', 80055 Naples, Italy

3 Department of Veterinary Medicine and Animal Production, University of Napoli Federico II, 80100 Naples, Italy; tudisco@unina.it (R.T.); nadia.musco@unina.it (N.M.); infascel@unina.it (F.I.); pilombar@unina.it (P.L.)

4 Department of Biomedical Sciences, University of Cagliari, Monserrato, 09042 Cagliari, Italy; claumanca@unica.it (C.M.); banni@unica.it (S.B.)

5 Department of Pharmacy, University of Naples Federico II, 80131 Naples, Italy

6 Department of Experimental Medicine, Section of Human Physiology and Unit of Dietetics and Sports Medicine, Università degli Studi della Campania “Luigi Vanvitelli”, 80138 Naples, Italy; marcellino.monda@unicampania.it

7 Institute of Food Sciences, National Research Council, 83100 Avellino, Italy

* Correspondence: paolo.bergamo@isa.cnr.it; Tel.: +39-08-2529-9506

+ Both authors contributed equally to this work.

Abstract: Milk contains several important nutrients that are beneficial for human health. This review considers the nutritional qualities of essential fatty acids (FAs), especially omega-3 ( $\omega-3)$ and omega- 6 $(\omega-6)$ polyunsaturated fatty acids (PUFAs) present in milk from ruminant and non-ruminant species. In particular, the impact of milk fatty acids on metabolism is discussed, including its effects on the central nervous system. In addition, we presented data indicating how animal feeding-the main way to modify milk fat composition-may have a potential impact on human health, and how rearing and feeding systems strongly affect milk quality within the same animal species. Finally, we have presented the results of in vivo studies aimed at supporting the beneficial effects of milk FA intake in animal models, and the factors limiting their transferability to humans were discussed.

Keywords: human health; milk; fatty acids; animal feeding; brain functions; omega-3 PUFAs; omega6 PUFAs; CLA

\section{Introduction}

In recent years, awareness of the importance of diet for human health has considerably increased, and some consumers, mainly living in developed countries, are paying more attention to selecting food that may directly contribute to their health [1]. Thus, food is no longer intended only to satisfy hunger and to provide the necessary nutrients, but also to prevent metabolic diseases and to improve the wellness of consumers [2].

Healthy nutrition, together with physical activity, positively affects metabolic health, the immune system, and lowers the risk of chronic illnesses and infectious diseases [3]. A variety of selected nutrients such as vitamins, minerals, dietary fibers, proteins, antioxidants, and fatty acids (FAs), but also drinking enough water and limiting sugar, fat, and 
salt, significantly lower the risk of several pathologies such as overweightness, obesity, heart disease, stroke, diabetes, neuro-pathologies, and certain types of cancer [4].

Common dietary recommendations for human health suggest limiting the consumption of several foods of animal origin [4] and, in general, to reduce saturated fatty acids (SFAs) and trans fatty acids to lower the incidence of cardiovascular disease [5]. Nonetheless, many studies demonstrated no association between the consumption of full-fat dairy and the risk of cardiometabolic diseases [6]. In this regard, milk deserves a dedicated discussion.

Milk is consumed by over 6 billion people around the world. Fats from milk and dairy products are an important source of nutrients and energy, but they have been reported as being implicated in some chronic diseases in humans [7]. Indeed, it is commonly suggested to use low-fat or reduced-fat products [8]. Nonetheless, recent studies have shown that milk and dairy, regardless of their fat content, may have a beneficial effect on metabolic and cardiometabolic health $[9,10]$. With regard to the effects of milk on brain health, although some studies indicated a positive impact of dairy consumption on cognitive performance and in reducing the risk of dementia [11,12], most of the results are still controversial [13-15]. In particular, little is known about the mechanisms linking milk/dairy intake and cognitive performance, and, in general, there is a lack of knowledge of the efficacy of individual milk nutrients on the central nervous system (CNS). Therefore, our review will focus on the effects of some FAs present in milk on human health, including the impact on the CNS.

It is important to underline that the term "milk" is vague since different animal species yield milk of different quality, with different compositions of FAs. Interestingly, the particular species-specific milk composition, especially protein and fat content, determine the rate of growth of the offspring of each mammalian species [16]. In addition, within the same animal species, and even within the same breed, the quality of milk strongly depends on several factors, such as animal feeding, rearing systems, and seasonal variability. Thus, in our review we will analyze the differences in the FA profiles of milk produced by different animal species, and by animals reared and fed in different ways.

\section{Profile of Milk Fat}

Milk contains numerous important nutrients such as FAs (oleic acid, $\omega-3$ FAs), protein, lactose, mineral salts (calcium, phosphorus, potassium, magnesium, sodium), and vitamins (especially B1, B2, B6, retinol, carotenes, tocopherol). The FA profile of milk is an important factor in determining its nutritional value $[10,17]$, with special attention paid to essential FAs, namely linoleic acid (LA, C18:2 $\omega-6$ ) and $\alpha$-linolenic acid (ALA, C18:3 $\omega-3$ ), which contribute to the human daily intake of polyunsaturated fatty acids (PUFAs). These FAs cannot be synthesized in humans [18].

\section{Polyunsaturated Fatty Acids (PUFAs)}

FAs are important components of the human body, playing several structural and functional roles. They are not only an important source of energy, but they are also key components of cell membranes' phospholipids, contributing to the fluidity, flexibility, and permeability of the membrane [19]. Key FAs are $\omega-3$ PUFAs, which participate in the inflammatory cascade, reducing the oxidative stress and playing a protective role in the cardiovascular and nervous systems $[20,21]$. The ALA in normal conditions cannot be converted efficiently to more biologically active PUFAs such as very long-chain eicosapentaenoic acid (EPA), docosahexaenoic acid (DHA), and docosapentaenoic acid (DPA, 22:5 $\omega-3)$ [22], which have to be assumed by diet. Milk and dairy products contribute about $16-26 \%$ of the human daily intake of $\omega-3$ PUFAs [23].

The main $\omega-6$ FA in cow milk fat, LA, is required for the synthesis of arachidonic acid (AA, C20:4, $\omega-6$ ) and eicosanoids [24]. The term conjugated linoleic acid (CLA) indicates a group of LA isomers with conjugated double bonds, produced in the rumen as well as in the mammary gland by $\Delta 9$-desaturase activity [25-28]. In particular, CLA refers to two isomers: the cis- 9 , trans-11 ( $99, \mathrm{t} 11$; also known as rumenic acid, RA) and, at a much lower concentration, the trans-10, cis-12 (t10, c12) isomer, which are mainly present in the milk of 
ruminant animals [17]. RA is the main CLA component, accounting for $90 \%$ of the total CLA in ruminant fat [29], but a range of cis-trans or trans-trans CLA isomers with the trans bond at C-7 to C-14 and the cis bond at C-9 to C-13 are also found. CLA isomers are naturally produced in the rumen as intermediates of the gut bacterial biohydrogenation of dietary LA and ALA, present in fresh grass, to stearic acid [30]. Alternatively, they may originate from endogenous synthesis in the mammary gland by the action of stearoyl-CoA desaturase on trans11 C18:1 (trans-vaccenic acid, tVA) [31].

\section{Milk Fatty Acid Composition in Different Animal Species}

Milk for human nutrition produced worldwide mainly comes from cows (about 85\%), followed by buffalo (11\%), goat $(2.3 \%)$, sheep $(1.4 \%)$, and camel $(0.2 \%)$, while milk from other dairy species such as horse, donkey, and yak, accounts for less than $0.1 \%$ [32].

\subsection{Ruminants Milk}

The milk of ruminants is characterized by a high content of SFAs (about $70 \%$ of total FAs), a low content of PUFAs (less than $3 \%$, including $\omega-3$ FAs and CLA, mainly RA), and trans-FAs $(\sim 4 \%$, including vaccenic acid or trans-11 C18:1) $[33,34]$. There are relevant differences between species (Table 1): milk fat content is higher in sheep (6-7 g/100 g of milk) than in cows (3.5-3.8 g/100 $\mathrm{g}$ of milk) or goats (3.6-4 g/100 $\mathrm{g}$ of milk) [35]. In addition, the fat of milk from sheep and goats contains high levels of short- and medium-chain FAs with a carbon chain consisting, respectively, of 4-10 or 11-15 carbon atoms. In fact, the FAs known as caproic (C6:0), caprylic (C8:0), and capric (C10:0) are typical of goat milk and represent up to 15-18\% of the total milk FAs, compared to 5-9\% of cow's milk [36], which also helps to improve milk digestibility. In cow milk fat the main $\omega-6$ FA is LA, which is required for the synthesis of AA (C20:4, $\omega-6)$ and eicosanoids [24].

Table 1. Milk fat and fatty acid profiles in ruminant and non-ruminant species (data from [37-42]).

\begin{tabular}{ccccccc}
\hline & Cow & Buffalo & Sheep & Goat & Horse & Donkey \\
\hline Fat $(\mathrm{g} / 100 \mathrm{~g})$ & $3.3 .-6.4$ & $5.3-15.0$ & $4.0-9.0$ & $3.0-7.2$ & $0.4-7.2$ & $0.3-1.8$ \\
\hline \multicolumn{7}{c}{$\%$ of total FAs } \\
\hline SFAs & $55.0-73.0$ & $62.0-74.0$ & $57.0-75.0$ & $59.0-74.0$ & $37.0-55.0$ & $46.0-68.0$ \\
MUFAs & $2.0-30.0$ & $24.0-29.0$ & $23.0-39.0$ & $19.0-36.0$ & $18.0-36.0$ & $15.0-35.0$ \\
PUFAs & $2.4-6.3$ & $2.3-3.9$ & $2.6-7.3$ & $2.6-5.6$ & $13.0-51.0$ & $14.0-30.0$ \\
CLA & $0.2-2.4$ & $0.4-1.0$ & $0.6-1.1$ & $0.3-1.2$ & $0.02-0.1$ & Trace \\
$\omega-6$ & $1.2-3.0$ & $1.74-2.0$ & $1.6-3.6$ & $1.9-4.3$ & $3.6-20.3$ & $6.0-15.2$ \\
$\omega-3$ & $0.3-1.8$ & $0.2-1.4$ & $0.5-2.3$ & $0.3-1.48$ & $2.2-31.2$ & $4.0-16.3$ \\
\hline
\end{tabular}

SFAs, saturated fatty acids; MUFAs, mono-unsaturated fatty acids; PUFAs, polyunsaturated fatty acids, $\omega-3$, omega-3; $\omega-6$, omega- 6 .

Buffalo milk contains more than twice the amount of fat (7.5-8.7 vs. 3.5-3.8 g/100 g milk) than cow milk, resulting in higher energy content. The percentage of SFAs $(65-75 \mathrm{~g} / 100 \mathrm{~g}$ of total FAs) is comparable to cow milk. The high fat content makes buffalo milk particularly suitable for the production of dairy products (e.g., mozzarella cheese, a typical fresh and stringy-textured cheese) [43].

Goat milk is recommended for consumers who are allergic to cow milk. It contains high levels of butyric (C4:0), caproic (C6:0), caprylic (C8:0), capric (C10:0), lauric (C12:0), myristic (C14:0), palmitic (C16:0), and linoleic (C18:2) acids, but low levels of stearic (C18:0) and oleic (C18:1) acids. At least 20\% of the FAs in goat milk are short chain FAs, which are readily digested [44], and the content of medium-chain FAs is relatively high [45].

Sheep milk shows significantly higher levels of caproic (C6:0), caprylic (C8:0), capric (C10:0), and lauric (C12:0) acids than cow milk [46]. These short- and medium-chain FAs are associated with the characteristic flavors of cheeses. In addition, sheep milk is characterized by a higher concentration of butyric acid (C4:0) and $\omega-3$ FAs than other ruminant milk [47]. 


\subsection{Non-Ruminants (Monogastric Animals) Milk}

Equid milk is characterized by a total fat content $(0.8-1.5 \%)$ much lower than human milk (3.5-4.2\%) and a unique lipid composition. The FA composition and, in particular, the percentage of total PUFAs of horse and donkey milk are high. The $\omega-3$ PUFA content averages $8.66-11.97 \%$ and $9.45-9.64 \%$ of total FAs for horse and donkey milk, respectively. Furthermore, eicosapentaenoic acid (C20:5 $w-3)$, DHA (C22:6 $w-3)$, and AA (C20:4 $\omega-6)$ levels in horse and donkey milk are below $0.5 \mathrm{~g} / 100 \mathrm{~g}$ FAs $[48,49]$.

Donkey and horse milk have been used in human nutrition since ancient times, in particular as a cow milk substitute for allergic/intolerant people and elderly consumers [49], and as foods with health-promoting properties related to their peculiar lipid composition and lactose contents [50]. It is noteworthy that donkey and human milk are both characterized by a peculiarly high concentration of palmitic acid in the sn-2 position of the triacylglycerol backbone that seems to play a crucial role in the regulation of energy and lipid metabolism [51]. Accordingly, the administration of donkey and human milk to rats displayed several beneficial effects on lipid and glucose metabolism compared to animals fed cow milk [37,52-54]. It has been hypothesized that this effect depends on the modulation of oleoylethanolamide (OEA) and palmitoylethanolamide (PEA) levels [55], an endogenous ligand of the nuclear peroxisome proliferators-activated receptor (PPAR)- $\alpha$, which regulates fatty acid metabolism [56,57].

\subsection{Human Milk}

It is noteworthy that the primary source of the nutrients and lipids, including monounsaturated (MUFAs), $\omega-6$, and $\omega-3$ FAs, necessary for human development is maternal milk $[58,59]$. Since humans are unable to synthesize $\omega-6$ or $\omega-3$ FAs, all the fatty acids secreted into human milk are derived from the maternal diet. Thus, differences in maternal lipid nutrition during lactation can result in large differences in $\omega-6$ and $\omega-3$ FAs in human milk [60].

In human milk, the amount of fat (3.8-4.2\%) is similar to cow milk, while the composition of FAs is very different from cow milk and more similar to donkey milk. Indeed, human milk fat is high in unsaturated fatty acids and PUFAs, particularly the essential fatty acids LA and ALA. The beneficial effects of human milk also depend on its bioactive/immunomodulatory factors (oligosaccharides, lactose, glycosaminoglycans) [61]. The World Health Organization recommends the exclusive breastfeeding of infants for the first 6 months of age, since maternal milk reduces the incidence of neonatal necrotizing enterocolitis, gastroenteritis, respiratory infection, and immunologically based disease, and improves later cognitive development $[62,63]$.

\section{Factors Affecting Fatty Acid Profiles in Milk from Different Animal Species}

Dairy research initially focused on increasing milk yield and the production efficiency of cows. During the past few decades, consumers and industry demand for healthy and sustainable foods motivated the great research efforts aimed at investigating the factors influencing the nutritional quality of the final product. Animal milk composition is affected by several factors (animal breed, health status, stage of lactation, feeding regimen, and seasons), and among them, animal diet was recognized as an effective way to maximize the content of beneficial FAs in milk ( $\omega-3$ PUFAs, tVA, and RA) [64]. Manipulating the diet of cows, as well as of goats and sheep, was an effective way to increase the healthpromoting FA content of milk $[47,65]$. Accordingly, the beneficial effect of the feeding practices used in organic husbandry on cow, goat, and sheep milk FA composition was demonstrated [66-70].

As demonstrated in sheep, the higher levels of ALA in milk from the grazing group were due to the higher content of ALA in the pasture, as opposed to in alfalfa hay [71]. Thus, grazing is a useful tool for increasing the levels of milk PUFAs [72], as shown in sheep, dairy cows, dairy buffalos, and dairy goats [69,73-76]. 
In addition, it was reported that the highest PUFA values in the milk of the grazing group occurred in June and September, in accordance with the pasture's fatty acid profile during the trial [77,78]. A similar result was also reported in grazing sheep [79-81]. The higher levels of c9, t11 CLA and t10, c12 CLA detected in the milk from grazing animals could be also due to the higher levels of LA and ALA, the main CLA precursors, which were higher in the pasture than in the hay [82]. Indeed, according to Aii et al. [83], the hay making process determines a loss in these fatty acids. Thus, the pasture, especially when rich in ALA, represents a good strategy for improving the lipid composition of milk in ruminant species. In addition, grazing, or at least using fresh forage, may represent a low-cost approach when compared to supplementing the diet with oilseeds or fats [84]. According to Benbrook et al. [85], a significant decrease of LA, higher levels of ALA, long-chain $\omega-3$ FAs, total CLA, and a $\omega-6 / \omega-3$ ratio close to 1 can be achieved in milk by increasing the forage portion of the diet of dairy cows. Finally, Davis et al. [86] reported a $94 \%$ and $92 \%$ increase in CLA and $\omega-3$ FA, respectively, as well as a significant decrease in the $\omega-6 / \omega-3$ ratio in milk from grazing dairy cows.

It is noteworthy that dairy products' FA profiles mainly depend on raw milk content, rather than cheese processing methods $[27,87,88]$. Sheep cheese has higher levels of beneficial PUFAs than cow and goat cheese, making the improvement of FA profiles in this cheese particularly interesting from a nutritional point of view [88]. Cheese fats produced by milk from grazing animals or animals fed high amounts of fresh forage have higher proportions of $\omega-3$ FAs vs. conventional cheese because forages are naturally rich sources of C18:3 $\omega-3[89,90]$. Additionally, higher levels of PUFAs and MUFAs, lower percentages of SFAs, higher content of C18:3 and CLA, and a better atherogenic index value have been reported for buffalo mozzarella cheese when the animals were fed fresh forage [91].

Ruminants' diet may also affect the milk concentration of the other two classes of bioactive FAs: (i) the branched-chain fatty acids (BCFAs), characterized by anti-tumor activity [92] and the ability to decrease the incidence of necrotizing enterocolitis [93] and to support pancreatic $\beta$-cell function [94]; and (ii) the odd-chain fatty acids (OCFAs), which reduce the risk of type-2 diabetes [95,96] and cardiovascular diseases [96,97]. The main source of odd- and branched-chain fatty acids (OBCFAs) in the human diet is represented by ruminant fats. Indeed, they are synthesized de novo by the rumen microbial flora [98], but linear OCFAs (C15:0 and C17:0) and anteiso-isomers can be also produced in the mammary gland $[98,99]$. These multiple origins could explain their higher concentration than other OBCFAs in goat [100] and cow milk [93,101,102]. Lopez et al. [103] reported significantly higher OBCFA concentration in organic goat (4.7\%) than in conventional milk (3.4\%). Significantly higher levels of total OBCFAs are reported in milk from goats fed a diet with a high, rather than low, forage:concentrate ratio [103-105]. This high level may be due to a better equilibrium in the rumen bacterial populations with the administration of higher amounts of forage. In goats, milk OBCFA content was also significantly influenced by the diet lipid supplementation [106].

In this animal species, milk OBCFA content was also significantly influenced by the diet lipid supplementation and the forage:concentrate ratio [104-106]. Accordingly, Vlaeminck et al. [98] observed a decrease in milk OBCFAs in cows by increasing their dietary concentrate percentage from 20 to $70 \%$ [98]. In addition, milk from cows fed different pasture vegetation types showed significantly different contents of OCFAs (C15:0, C17:0, C17:1) [107].

\section{Polyunsaturated Fatty Acids Effects on Human Health}

\subsection{Polyunsaturated Fatty Acids Effects on Metabolism}

It is well known that a deficiency of $\omega-3$ FAs is detrimental for human health [108]. The practical way to increase levels of DPA, EPA, and DHA in the body does not depend exclusively on $\omega 3$ processing, but requires their intake directly from foods and/or dietary supplements. Indeed, the most recent dietary guidelines recommend the consumption of foods containing high levels of $\omega-3$ PUFAs. $\omega-3$ PUFAs exert beneficial effects [109] 
in lowering the risk of cardiovascular disease [110], in reducing the advancement of the atherosclerotic process in patients with coronary heart disease [20], in slowing down the growth of cancer, and in increasing the efficacy of chemotherapeutic treatments [111], as well as in lowering neuroinflammation and maintaining mental health [21]. In addition, DHA and EPA are considered potent anti-inflammatory products, able to reduce the risk of insulin resistance and ameliorate obesity-associated disorders [112,113]. Interestingly, in a rodent model with a high-fat diet regimen, it was demonstrated that the replacement of lard (rich in SFAs) with fish oil (rich in $\omega-3$ PUFAs) limited the development of systemic and tissue inflammation, reduced fat accumulation in the liver and skeletal muscle, attenuated insulin resistance and oxidative stress, and modulated mitochondrial efficiency $[114,115]$. Limited information is available on the biological effects of DPA in clinical studies, since pure DPA has become commercially available only recently.

The synthetic isomeric mixture (RA:t10, c12, 1:1) of CLA has a broad range of beneficial effects on inflammation, obesity, diabetes, and cancer [116,117]. It has been known for a long time that CLA isomers have distinct effects, although there is no complete agreement on their specific effects on sugar/lipid metabolism and anticancer activity. In particular, the pro-diabetic effect of t10, c12-CLA was initially demonstrated in obese subjects [118], while the anti-diabetic effects of RA were indicated by other studies [119-121]. Recently, the anti-inflammatory efficacy of RA was reported, while t10, c12-CLA was indicated as responsible for anti-carcinogenic, anti-obesity, and anti-diabetic effects [122]. In rodent models, it was demonstrated that RA had the ability to improve antioxidant detoxifying defences via the activation of the nuclear erythroid-related factor 2 (Nrf2) - which is the main pathway in the maintenance of redox status and metabolic and protein homeostasis, as well as in the regulation of inflammation [123-125]. In addition, it has been recently shown that CLA, by inducing PPAR- $\alpha$, greatly improves DHA biosynthesis from ALA in animal models [126] and in humans [127].

Interestingly, it was demonstrated that the milk obtained from cows treated with a different feeding/rearing system exhibited a different profile of milk PUFAs and had selective metabolic effects when administered to rodents. In particular, rats' diets were supplemented with milk produced by dairy cows fed with a high forage:concentrate ratio (70:30; high-forage milk), and with milk produced by cows fed with the low forage:concentrate ratio (55:45; low-forage milk) normally used in intensive farms. The high-forage milk had beneficial effects on the rats' lipid metabolism, inflammation, and oxidative stress, modulating mitochondrial function and efficiency in the liver and skeletal muscle. These data provided the first evidence that dietary supplementation with high-forage milk in rodents decreases lipid accumulation through an increase in fatty acid oxidation, and a decrease in inflammation and oxidative stress $[37,128]$. The beneficial effects of high-forage milk were similar to those resulting from $\omega-3$ and RA intake $[114,115,129,130]$, allowing the authors to hypothesize that $\omega-3$ and RA may be some of the key functional components of high-forage milk.

In an another set of experiments, mice were fed with high-fat diets containing either dairy cream obtained from the milk of cows fed on pastures, or standard cream. It was observed that the animals fed pasture dairy cream exhibited improved intestinal barriers, and this effect was attributed to the higher LA content of pasture dairy cream [131]. On the other hand, when mice models with chemically induced colitis were fed cow milk naturally enriched in RA (selected from commercially available organic blends), high cyto-protective effects were observed, presumably associated with RA's ability to trigger Nrf2-mediated antioxidant/detoxifying defenses [132].

The potential health benefits resulting from CLA intake, mainly obtained in animal models, led to its recognition as a functional food [133]. In clinical studies, the health effects produced by the intake of CLA-rich dairy products from goat or sheep milk were evaluated $[127,134,135]$. Since high CLA concentration improves the nutritional value of dairy foods, the production of dairy food enriched with RA was encouraged [136,137]. Surprisingly, despite the great number of studies that investigated the factors determining 
the concentration of health-promoting FAs in milk, only a limited number of analyses have been focused on the biological effects produced by the intake of RA-rich dairy products (Table 2). The main limitation of most of these studies is due to the inadequate evaluation of the role of RA on the observed effects, and the lack of conversion of the RA-enriched supplement into doses that can be, reasonably, consumed by humans $[127,134,138]$. Interestingly, the intake of dairy products naturally enriched in RA and tVA (organically produced) was demonstrated to increase the content of these FAs in the milk of lactating women [139-141]. On the other hand, results related to the protective effect of RA-rich dairies against breast cancer are still controversial [128,129].

Table 2. Summary of the main studies focused on the biological effects produced by the intake of RA-rich dairy products (data from $[37,127,128,131,134,142-150])$.

\begin{tabular}{|c|c|c|c|}
\hline & Study & Treatment & Outcome \\
\hline \multicolumn{4}{|l|}{ Animal models } \\
\hline & Female growing pigs & RA-enriched butter & $\begin{array}{l}\text { Undetectable effects on blood } \\
\text { lipoproteins [142] }\end{array}$ \\
\hline & Wistar rats & RA-enriched clarified butter & $\uparrow$ Antioxidants [143] \\
\hline & Wistar rats & RA-enriched butter & 个 HDL, Triacylglycerol [144] \\
\hline & Mice fed high fat diet & Pasture dairy cream & $\begin{array}{l}\downarrow \text { Inflammation, Triacylglycerol } \\
\uparrow \text { Protective cells in the gut [131] }\end{array}$ \\
\hline & Wistar rats & RA-enriched butter & $\uparrow$ PLA2 [145] \\
\hline & $\begin{array}{l}\text { Mouse model of chemically } \\
\text {-induced (DSS) colitis }\end{array}$ & RA-enriched butter & $\begin{array}{l}\uparrow \text { Nrf-2- mediated defenses } \\
\quad \downarrow \text { Colitis signs [146] }\end{array}$ \\
\hline & Wistar rats & RA-enriched butter & $\uparrow$ Mitochondrial function [37] \\
\hline & Wistar rats & RA-enriched butter & $\begin{array}{c}\downarrow \text { Muscle inflammation, oxidative stress } \\
\uparrow \text { Mitochondrial function [128] }\end{array}$ \\
\hline \multicolumn{4}{|l|}{ Clinical studies } \\
\hline & Healthy middle-age subjects & Naturally enriched dairy products & $\begin{array}{l}\text { Undetectable effects on blood } \\
\text { lipoproteins [147] }\end{array}$ \\
\hline & $\begin{array}{l}\text { Healthy normal-weight and } \\
\text { over-weight subjects }\end{array}$ & Naturally enriched cheese & $\downarrow$ IL-6, Tnf- $\alpha[148]$ \\
\hline & Hypercholesterolemic subjects & Naturally enriched cheese & $\downarrow$ LDL [134] \\
\hline & Healthy young subjects & Naturally enriched cheese & $\begin{array}{c}\uparrow \text { IL-10 } \\
\downarrow \text { NFkB, Tnf- } \alpha, \text { IL-2, IL-8 [149] }\end{array}$ \\
\hline & Meta-analyses & CLA enriched food & $\downarrow$ LDL, cholesterol [150] \\
\hline & Healthy middle-age subjects & RA enriched cheese & $\begin{array}{l}\uparrow \text { Highly unsaturated fatty acids in } \\
\text { blood plasma [127] }\end{array}$ \\
\hline
\end{tabular}

RA, rumenic acid; HDL, high density lipoprotein; PLA2, phospholipase A2; DSS, dextran sulfate sodium; Nrf-2, nuclear factor E2-related factor 2; IL-6, interleukin-6; Tnf- $\alpha$, tumor necrosis factor- $\alpha$; LDL, low density lipoprotein; IL-10, interleukin-10; NFkB, nuclear factor kappa-beta; IL-2, interleukin-2; IL-8, interleukin-8; CLA, conjugated linoleic acid.

Taken together, these results indicate that, although nutritional benefits may potentially be provided by the intake of dairy foods with improved RA content, additional investigation with multi-center clinical trials is necessary to identify the population more responsive to them.

\subsection{Polyunsaturated Fatty Acids Effects on Nervous System}

The brain requires an outstanding energy supply to maintain its dynamic abilities and its complex architecture. Indeed, the adult brain, which accounts for about $2 \%$ of body weight, utilizes $20 \%$ of the oxygen and $20-25 \%$ of the glucose [151]. In addition, the huge brain size expansion during the first few years of life requires specific nutrients, 
such as lipids, proteins, and micronutrients, which are also necessary to support neuronal connectivity and brain cognitive functions in adulthood. Thus, the appropriate nutritional management of the brain has a crucial relevance throughout the whole life [152]. It has been widely recognized that dietary regimen affects brain health and the appropriate choice of diet can reduce the risk of mental illness. Although no single dietary component has been identified as crucial in improving brain wellness, eating habits and the synergistic interaction between different nutrients seem to have beneficial effects in preventing mental health disorders [153]. Thus, diet and its bioactive components are among the modifiable risk factors possibly influencing the development of neuro-pathologies. In particular, SFAs and simple carbohydrates seem detrimental for the brain, while PUFAs, polyphenols, and antioxidants appear to be neuroprotective [154-156].

The brain is the second organ richest in lipids after adipose tissue, with $35 \%$ of brain lipids made by PUFAs. The biosynthesis of PUFAs in the brain is very low, and most of them are biosynthesized in the liver, although the contribution of diet is also critical and mainly dependent on fish consumption, which is often under the recommended daily intake [157-159]. The most abundant PUFAs in the brain are $\omega-6$ AA and $\omega-3$ DHA, which are components of plasma membranes' phospholipids in neuronal cells [21]. $\omega-3$ DHA is indispensable in maintaining membrane integrity and, as a consequence, membrane ionic permeability, neuronal excitability, mitochondrial activity, and synaptic functions. Thus, DHA is crucial for the normal development of the CNS, and its deficiency can impair cerebral functions, leading to neuropsychiatric disorders such as depression or dementia [159]. Animal models with a chronic deficiency of dietary $\omega-3$ PUFAs, from conception to the early stage of development, exhibited a decreased concentration of DHA in neuron membranes, leading to retarded visual acuity, impaired learning ability, and several neurological disorders $[21,157]$. Since having the correct supply of $\omega-3$ PUFAs during development is so important for brain activity, the fetus receives the necessary PUFAs through the placenta, and the newborn receives them by breast-feeding [21]. This is one of the reasons for highly recommend breast-feeding for infant nutrition. Since breastfeeding may not always be possible or suitable, infant formula is the industrial substitute for newborn nutrition [160]. In this regard, it has been demonstrated that adding DHA to formulas for bottle-fed human infants increases their blood concentration of DHA to values similar to breast-feeding infants and significantly improves mental development [157]. The importance of the correct supply of $\omega-3$ PUFAs during the brain development was also demonstrated using an interesting experimental paradigm. Rats were exposed to a diet deficient in $\omega-3$ FAs during the brain maturation period. When they became adults, their diet was switched to a Western diet, and they were subjected to mild traumatic brain injury, a risk factor for the development of psychiatric illness. In the animals exposed to this diet switch, compared to controls, the mild brain injury induced more severe anxiety-induced disorders, and the downregulation of the brain's levels of brain derived neurotropic factor (BDNF) and its signalling pathway was observed [161]. These data underlined how incorrect dietary habits during development might lower the threshold for neurological disorders later in life. Interestingly, patients with depression display lower levels of $\omega$-3 PUFAs [162] and decreased serum levels of BDNF [163]. Accordingly, the administration of $\omega-3$ PUFAs stimulated BDNF expression and adult hippocampal neurogenesis in mice [164-166].

Since BDNF is a protein known to couple energy metabolism and synaptic plasticity [158], it is possible to suggest that dietary PUFA is acting as an energy modulator in cognitive functions, affecting, in particular, the synaptic regions [167]. From this point of view, it is interesting to underline that some neurodegenerative diseases, as well as aging processes, share, as a common feature, synaptic dysfunctions, and therefore are defined as "synaptopathies" [168-172]. Interestingly, PUFAs play critical roles at the synapses, where they are involved in synaptogenesis, synapse maintenance, and synapse function [168]. Thus, understanding PUFAs' action mechanisms at synaptic areas will open the way to an innovative and promising strategy to treat synaptopathies using PUFA dietary sup- 
plementation which may restore the impaired synaptic functions [168]. Recently, using a very elegant experimental approach, it was demonstrated that DHA is able to mitigate the presynaptic over-inhibition of animal model autism spectrum disorders [173].

Interestingly, $\omega-6$ and $\omega-3 F A s$ are precursors of highly bioactive molecules, produced by the enzymatic (i.e.,cyclooxygenases and lipoxygenases) or non-enzymatic metabolism of $\alpha, \beta$-unsaturated aldehydes (e.g., 4-hydroxynoneal and 4-hydroxyhexenal), cyclopentenone metabolites (e.g., isoprostanes and neuroprostanes), nitrated fatty acids (e.g., $\mathrm{NO}_{2}$-CLA, $\mathrm{NO}_{2}$-LA), and specialized pro-resolving mediators (e.g., lipoxins, resolvins and maresins) involved in the initiation, progression, and resolution of the inflammatory process [21]. The brain is particularly susceptible to oxidative stress because it has a high demand for oxygen, high concentrations of iron, and relatively low antioxidant capacity, as well as high content of PUFAs, which are source of oxygen radicals through lipid peroxidation $[174,175]$. Oxidation of membrane PUFAs alters the fluidity of membranes, damages membrane receptors structures, causes mitochondrial dysfunction, and deteriorates cellular components, thus contributing to neuronal degeneration and impaired neuronal communication [167].

Interestingly, it was observed that DHA from dietary sources is incorporated into mitochondrial and synaptosomal membranes in mouse brains [176]. Mitochondrial phospholipids are particularly rich in DHA that promotes mitochondrial biogenesis and modulates the expression of genes associated with energy metabolism and ATP production [177]. Alteration of the mitochondrial oxidative capacity is linked to brain aging and plays a crucial role in the onset and progression of neurodegenerative diseases, such as Alzheimer's, Parkinson's, Huntington's disease, and ischemic stroke [159,178]. Interestingly, the ability of $\omega-3$ PUFA to reverse inflammation, oxidative stress, and altered mitochondrial functions has been demonstrated as observed in animal models of obesity [179]. These data suggest that these FAs have a pivotal role in mitochondrial functions and efficiency.

CLA is able to cross the blood-brain barrier and be incorporated and metabolized in the brain, where it plays different roles $[180,181]$. Peculiarly, CLA has been shown to induce the biosynthesis of endogenous PPAR- $\alpha$ ligands, PEA and OEA, likely through a positive feedback mechanism where PPAR- $\alpha$ activation sustains its own cellular effects through ligand biosynthesis [182]. In addition to PPAR- $\alpha$, PEA and OEA can activate, indirectly or directly, other receptors such as transient receptor potential vanilloid 1 (TRPV1) [183,184], which are also implicated in metabolism regulation and anti-inflammatory activity [185]. These data further extend CLA anti-neuroinflammatory actions, demonstrated in cultured astrocytes [186] and in vivo, where it has been shown that chronic dietary CLA intake reduces prostaglandin E2, decreases the activity of the endocannabinoid system, and inhibits angiogenesis in the mammalian brain [187-189]. In a murine model of autoimmune disease, it has been shown that the protective effect of CLA on age-dependent biochemical signs of neurodegeneration and depression are associated with the activation of Nrf2-mediated cytoprotective defences $[190,191]$. In addition, CLA protects against the disease-associated decline of synaptogenesis [190]. Moreover, RA has been shown to protect mouse cortical neurons from glutamate excitotoxicity [192]. Interestingly, the CLA supplementation of pregnant rats affects brain functions in offspring. Indeed, a maternal CLA-rich diet during gestation and lactation results in beneficial effects on neurodevelopment, improving learning and memory in the newborn rats [193] (Figure 1). 


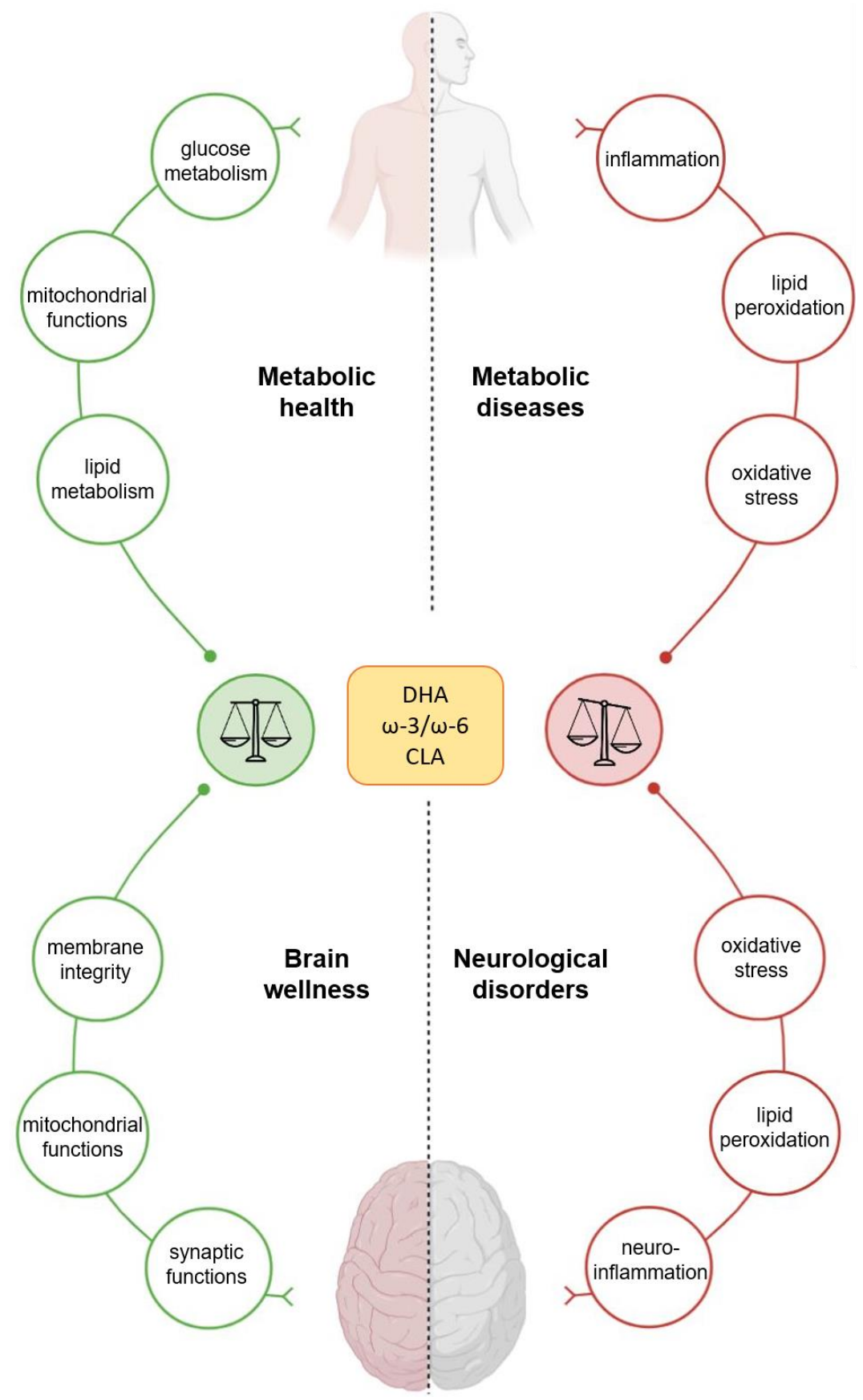

Figure 1. Effects of docosahexaenoic acid (DHA), conjugated linoleic acid (CLA), and $\omega-3 / \omega-6$ on human wellness. The nutritional supply of DHA, CLA, and $\omega-3-\omega-6$ PUFAs has a great impact on human health, affecting the metabolism of peripheral organs and the brain's functions.

\section{Conclusions}

FAs composition of dairy products varies among different species, and it is strongly influenced by animal nutrition. Milk and dairy products greatly contribute to human daily intake of FAs that, beside their function as structural components of cells and metabolic substrate, also play a crucial role as signaling molecules. Peculiarly, a higher content of potentially beneficial FAs adds nutritional/functional value to dairy products. Numerous comparative evaluations have been conducted in different animal species, nutritional strategies have been developed, and increased commercial attention is accompanying "enriched" products. Unfortunately, there are very few in vivo data supporting their beneficial activities, and most of them have been obtained by using pure FAs (mainly 
$\omega$-3 PUFAs), rather than FAs naturally incorporated into enriched milk/cheese, which may possess distinct biological activities compared to the pure FAs. Thus, although our review provides various evidence of the beneficial effects of dietary PUFAs, characteristic of milk and dairy products, on metabolic and neuronal functions, more preclinical and clinical studies are warranted to confirm and further investigate the effects of milk and dairy products on human health (Figure 2).

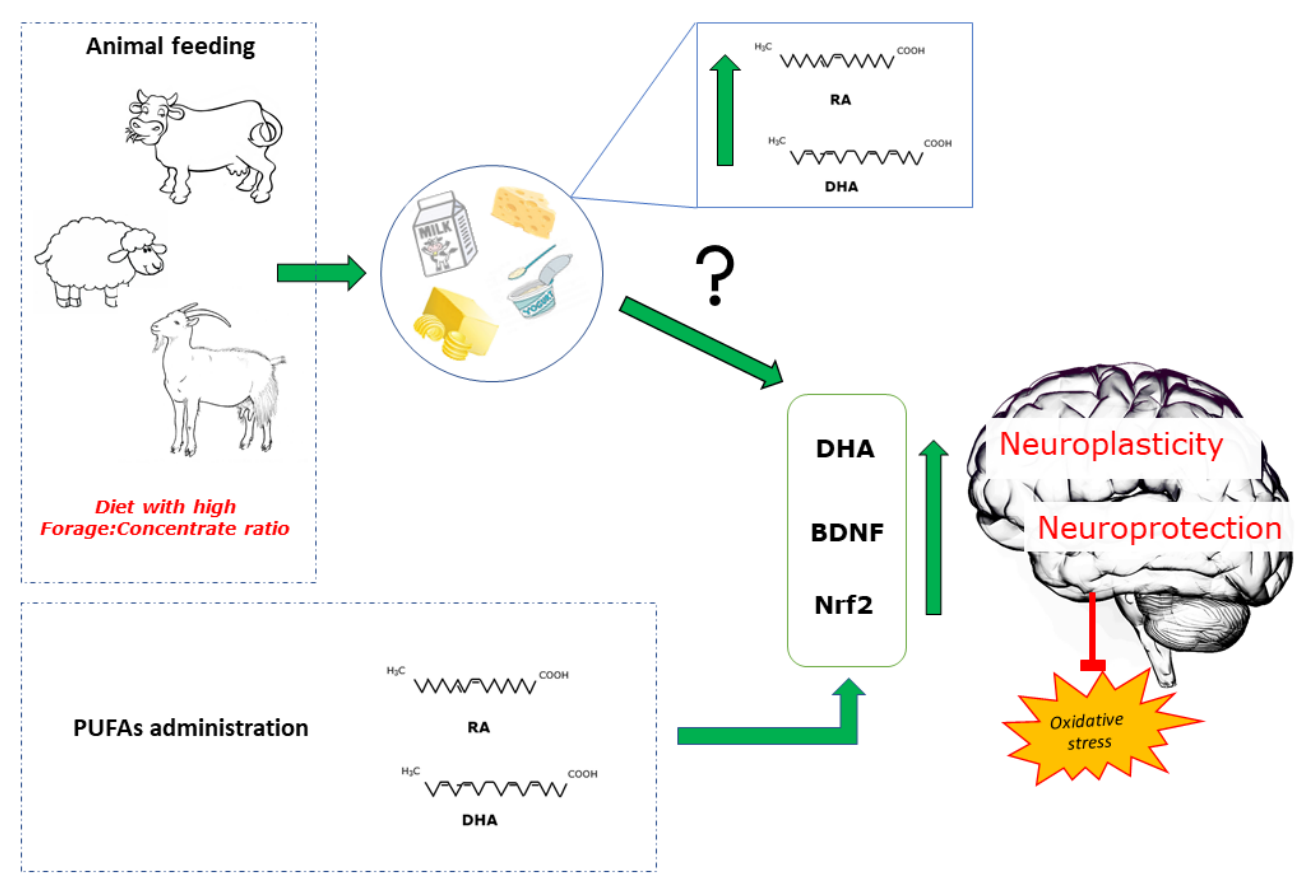

Figure 2. Animal feeding systems affect the profile of milk PUFAs (rumenic acid, RA; docosahexaenoic acid, DHA). Studies related to the effects of milk administration on metabolic and brain health yielded controversial results. Administration of pure PUFAs increases DHA brain content, stimulates brain-derived neurotrophic factor (BDNF) expression in several brain areas, and activates the nuclear erythroid-related factor 2 (Nrf2) in the brain. These factors participate in redox homeostasis and modulate inflammatory state, contributing to neuroplasticity and neuroprotection.

Author Contributions: Conceptualization, M.P.M., M.C., P.L., P.B. and F.I.; writing-original draft preparation, M.P.M., G.T., R.T., F.I., P.L., P.B. and M.C.; writing-review and editing, M.P.M., G.T., E.P., F.C., G.C., A.C., P.B., S.B., R.T., N.M., C.M., M.M., F.I., P.L. and M.C.; visualization, E.P. and F.C.; supervision, M.P.M., S.B. and M.C. All authors have read and agreed to the published version of the manuscript.

Funding: This research received no external funding.

Conflicts of Interest: The authors declare no conflict of interest.

\section{Abbreviations}

$\begin{array}{ll}\text { FAs } & \text { Fatty acids } \\ \text { LA } & \text { Linoleic Acid } \\ \text { CLA } & \text { Conjugated linoleic acids } \\ \text { PUFAs } & \text { Polyunsaturated fatty acids } \\ \text { SFAs } & \text { Saturated fatty acids } \\ \text { CNS } & \text { Central nervous system } \\ \text { AA } & \text { Arachidonic acid } \\ \text { EPA } & \text { Eicosapentaenoic acid }\end{array}$




$\begin{array}{ll}\text { DHA } & \text { Docosahexaenoic acid } \\ \text { RA } & \text { Rumenic acid } \\ \text { ALA } & \alpha \text {-linolenic acid } \\ \text { tVA } & \text { Trans-vaccenic acid } \\ \text { OEA } & \text { Oleoylethanolamide } \\ \text { PEA } & \text { Palmitoylethanolamide } \\ \text { PPAR } & \text { Peroxisome proliferators-activated receptors } \\ \text { BCFA } & \text { Branched chain fatty acids } \\ \text { OCFAs } & \text { Odd-chain fatty acids } \\ \text { OBCFAs } & \text { Odd-branched-chain fatty acids } \\ \text { BDNF } & \text { Brain derived neurotropic factor } \\ \text { Nrf } & \text { Nuclear factor erythroid 2-related factor } 2\end{array}$

\section{References}

1. Mollet, B.; Rowland, I. Functional foods: At the frontier between food and pharma. Curr. Opin. Biotechnol. 2002, 13, 483-485. [CrossRef]

2. Menrad, K. Market and marketing of functional food in Europe. J. Food Eng. 2003, 56, 181-188. [CrossRef]

3. Chooi, Y.C.; Ding, C.; Magkos, F. The epidemiology of obesity. Metabolism 2019, 92, 6-10. [CrossRef]

4. Burlingame, B.; Nishida, C.; Uauy, R.; Weisell, R. Fats and fatty acids in human nutrition: Introduction. Ann. Nutr. Metab. 2009, 55, 5-7. [CrossRef]

5. Kliem, K.E.a.S.K.J. Manipulation of milk fatty acid composition in lactating cows: Opportunities and challenges. Eur. J. Lipid Sci. Technol. 2016, 118, 1661-1683. [CrossRef]

6. Astrup, A.; Geiker, N.R.W.; Magkos, F. Effects of Full-Fat and Fermented Dairy Products on Cardiometabolic Disease: Food Is More than the Sum of Its Parts. Adv. Nutr. 2019, 10, 924S-930S. [CrossRef] [PubMed]

7. Shingfield, K.J.; Ahvenjärvi, S.; Toivonen, V.; Vanhatalo, A.; Huhtanen, P.; Griinari, J.M. Effect of incremental levels of sunflowerseed oil in the diet on ruminal lipid metabolism in lactating cows. Br. J. Nutr. 2008, 99, 971-983. [CrossRef] [PubMed]

8. Saturated Fats and Health; SACN Report: London, UK, 2019.

9. Timon, C.M.; O'Connor, A.; Bhargava, N.; Gibney, E.R.; Feeney, E.L. Dairy Consumption and Metabolic Health. Nutrients 2020, 12, 3040. [CrossRef] [PubMed]

10. Hirahatake, K.M.; Astrup, A.; Hill, J.O.; Slavin, J.L.; Allison, D.B.; Maki, K.C. Potential Cardiometabolic Health Benefits of Full-Fat Dairy: The Evidence Base. Adv. Nutr. 2020, 11, 533-547. [CrossRef]

11. Crichton, G.E.; Elias, M.F.; Dore, G.A.; Robbins, M.A. Relation between dairy food intake and cognitive function: The MaineSyracuse Longitudinal Study. Int. Dairy J. 2012, 22, 15-23. [CrossRef]

12. Ozawa, M.; Ohara, T.; Ninomiya, T.; Hata, J.; Yoshida, D.; Mukai, N.; Nagata, M.; Uchida, K.; Shirota, T.; Kitazono, T.; et al. Milk and dairy consumption and risk of dementia in an elderly Japanese population: The Hisayama Study. J. Am. Geriatr. Soc. 2014, 62, 1224-1230. [CrossRef] [PubMed]

13. Lee, J.; Fu, Z.; Chung, M.; Jang, D.J.; Lee, H.J. Role of milk and dairy intake in cognitive function in older adults: A systematic review and meta-analysis. Nutr. J. 2018, 17, 82. [CrossRef] [PubMed]

14. Cuesta-Triana, F.; Verdejo-Bravo, C.; Fernández-Pérez, C.; Martín-Sánchez, F.J. Effect of Milk and Other Dairy Products on the Risk of Frailty, Sarcopenia, and Cognitive Performance Decline in the Elderly: A Systematic Review. Adv. Nutr. 2019, 10, S105-S119. [CrossRef] [PubMed]

15. Zhang, X.; Chen, X.; Xu, Y.; Yang, J.; Du, L.; Li, K.; Zhou, Y. Milk consumption and multiple health outcomes: Umbrella review of systematic reviews and meta-analyses in humans. Nutr. Metab. 2021, 18, 1-18. [CrossRef]

16. Melnik, B.C. Milk-A Nutrient System of Mammalian Evolution Promoting mTORC1-Dependent Translation. Int. J. Mol. Sci. 2015, 16, 17048-17087. [CrossRef]

17. Jensen, R.G. The composition of bovine milk lipids: January 1995 to December 2000. J. Dairy Sci. 2002, 85, 295-350. [CrossRef]

18. Hu, F.B.; Manson, J.E.; Willett, W.C. Types of dietary fat and risk of coronary heart disease: A critical review. J. Am. Coll. Nutr. 2001, 20, 5-19. [CrossRef]

19. Medicine, I.O. Dietary Reference Intakes for Energy, Carbohydrate, Fiber, Fat, Fatty Acids, Cholesterol, Protein, and Amino Acids; The National Academies Press: Washington, DC, USA, 2005; p. 1358.

20. López, P.M.; Ortega, R.M. Omega-3 fatty acids in the prevention and control of cardiovascular disease. Eur. J. Clin. Nutr. 2003, 57, S22-S25. [CrossRef]

21. Haag, M. Essential fatty acids and the brain. Can. J. Psychiatry 2003, 48, 195-203. [CrossRef]

22. Burdge, G.C.; Calder, P.C. Conversion of alpha-linolenic acid to longer-chain polyunsaturated fatty acids in human adults. Reprod. Nutr. Dev. 2005, 45, 581-597. [CrossRef]

23. Benbrook, C.M.; Butler, G.; Latif, M.A.; Leifert, C.; Davis, D.R. Organic production enhances milk nutritional quality by shifting fatty acid composition: A United States-wide, 18-month study. PLOS ONE 2013, 8, e82429. [CrossRef]

24. Calder, P.C. Mechanisms of action of (n-3) fatty acids. J. Nutr. 2012, 142, 592S-599S. [CrossRef] 
25. Kepler, C.R.; Tove, S.B. Biohydrogenation of unsaturated fatty acids. 3. Purification and properties of a linoleate delta-12-cis, delta-11-trans-isomerase from Butyrivibrio fibrisolvens. J Biol. Chem. 1967, 242, 5686-5692. [CrossRef]

26. Griinari, J.M.; Corl, B.A.; Lacy, S.H.; Chouinard, P.Y.; Nurmela, K.V.; Bauman, D.E. Conjugated linoleic acid is synthesized endogenously in lactating dairy cows by Delta(9)-desaturase. J. Nutr. 2000, 130, 2285-2291. [CrossRef] [PubMed]

27. Collomb, M.; Schmid, A.; Sieber, R.; Wechsler, D.; Ryhänen, E.-L. Conjugated linoleic acids in milk fat: Variation and physiological effects. Int. Dairy J. 2006, 16, 1347-1361. [CrossRef]

28. Butler, G.; Collomb, M.; Rehberger, B.; Sanderson, R.; Eyre, M.; Leifert, C. Conjugated linoleic acid isomer concentrations in milk from high- and low-input management dairy systems. J. Sci. Food Agric. 2009, 89, 697-705. [CrossRef]

29. Chin, S.; Liu, W.; Storkson, J.; Ha, Y.; Pariza, M. Dietary sources of conjugated dienoic isomers of linoleic acid, a newly recognized class of anticarcinogens. J. Food Compos. Anal. 1992, 5, 185-197. [CrossRef]

30. Kepler, C.R.; Hirons, K.P.; McNeill, J.J.; Tove, S.B. Intermediates and products of the biohydrogenation of linoleic acid by Butyrinvibrio fibrisolvens. J. Biol. Chem. 1966, 241, 1350-1354. [CrossRef]

31. Corl, B.A.; Barbano, D.M.; Bauman, D.E.; Ip, C. cis-9, trans-11 CLA derived endogenously from trans-11 18:1 reduces cancer risk in rats. J. Nutr. 2003, 133, 2893-2900. [CrossRef]

32. Gerosa, S.; Skoet, J. Milk Availability Trends in Production and Demand and Medium-Term Outlook; Food and Agriculture Organization of the United Nations FAO: Rome, Italy, 2012.

33. Shingfield, K.J.; Chilliard, Y.; Toivonen, V.; Kairenius, P.; Givens, D.I. Trans Fatty Acids and Bioactive Lipids in Ruminant Milk. Adv. Exp. Med. Biol. 2008, 606, 3-65. [CrossRef]

34. Ferlay, A.; Bernard, L.; Meynadier, A.; Malpuech-Brugère, C. Production of trans and conjugated fatty acids in dairy ruminants and their putative effects on human health: A review. Biochimie 2017, 141, 107-120. [CrossRef] [PubMed]

35. Chilliard, Y.; Glasser, F.; Ferlay, A.; Bernard, L.; Rouel, J.; Doreau, M. Diet, rumen biohydrogenation and nutritional quality of cow and goat milk fat. Eur. J. Lipid Sci. Technol. 2007, 109, 828-855. [CrossRef]

36. Chilliard, Y.; Rouel, J.; Ferlay, A.; Bernard, L.; Gaborit, P.; Raynal-Ljutovac, K.; Lauret, A.; Leroux, C. Optimising Goat's Milk and Cheese Fatty Acid Composition; Elsevier: Amsterdam, The Netherlands, 2006; pp. 281-312.

37. Cavaliere, G.; Trinchese, G.; Musco, N.; Infascelli, F.; De Filippo, C.; Mastellone, V.; Morittu, V.M.; Lombardi, P.; Tudisco, R.; Grossi, M.; et al. Milk from cows fed a diet with a high forage: Concentrate ratio improves inflammatory state, oxidative stress, and mitochondrial function in rats. J. Dairy Sci. 2018, 101, 1843-1851. [CrossRef]

38. Correddu, F.; Serdino, J.; Manca, M.G.; Cosenza, G.; Pauciullo, A.; Ramunno, L.; Macciotta, N.P. Use of multivariate factor analysis to characterize the fatty acid profile of buffalo milk. J. Food Compos. Anal. 2017, 60, 25-31. [CrossRef]

39. D’Urso, S.; Cutrignelli, M.I.; Calabrò, S.; Bovera, F.; Tudisco, R.; Piccolo, V.; Infascelli, F. Influence of pasture on fatty acid profile of goat milk. J. Anim. Physiol. Anim. Nutr. 2008, 92, 405-410. [CrossRef]

40. Gantner, V.; Mijić, P.; Baban, M.; Škrtić, Z.; Turalija, A. The overall and fat composition of milk of various species. Mljekarstvo 2015, 65, 223-231. [CrossRef]

41. Tudisco, R.; Chiofalo, B.; Presti, V.L.; Morittu, V.M.; Moniello, G.; Grossi, M.; Musco, N.; Grazioli, R.; Mastellone, V.; Lombardi, P.; et al. Influence of Feeding Linseed on SCD Activity in Grazing Goat Mammary Glands. Animals 2019, 9, 786. [CrossRef] [PubMed]

42. Tudisco, R.; Morittu, V.M.; Addi, L.; Moniello, G.; Grossi, M.; Musco, N.; Grazioli, R.; Mastellone, V.; Pero, M.E.; Lombardi, P.; et al. Influence of Pasture on Stearoyl-CoA Desaturase and miRNA 103 Expression in Goat Milk: Preliminary Results. Animals 2019, 9, 606. [CrossRef]

43. Muehlhoff, E.; Bennet, A.; McMahon, D.; Food and Agriculture Organisation of the United Nations (FAO). Milk and Dairy Products in Human Nutrition (2013). Dairy Technol. 2014, 67, 303-304.

44. Jenness, R. Composition and Characteristics of Goat Milk: Review 1968-1979. J. Dairy Sci. 1980, 63, 1605-1630. [CrossRef]

45. Boza, J.; Sanz Sampelayo, M.R. Aspectos nutricionales de la leche de cabra (Nutritional aspects of goat milk). ACVAO 1997, 10, 109-139.

46. Goudjil, H.; Fontecha, J.; Luna, P.; De La Fuente, M.A.; Alonso, L.; Juárez, M. Quantitative characterization of unsaturated and trans fatty acids in ewe's milk fat. Le Lait 2004, 84, 473-482. [CrossRef]

47. Mohapatra, A.; Shinde, A.K.; Singh, R. Sheep milk: A pertinent functional food. Small Rumin. Res. 2019, 181, 6-11. [CrossRef]

48. Salimei, E.; Chiofalo, B. Asses: Milk yield and composition. In Nutrition and Feeding of the Broodmare; Miraglia, N., Martin-Rosset, W., Eds.; Wageningen Academic Publishers: Wageningen, The Netherlands, 2006; pp. 117-131, EAAP Publication No. 120.

49. Salimei, E.; Fantuz, F. Equid milk for human consumption. Int. Dairy J. 2012, 24, 130-142. [CrossRef]

50. Young, W.P.; George, F.W.H. Milk and Dairy Products in Human Nutrition: Production, Composition and Health, 1st ed.; John Wiley \& Sons, Ltd.: New York, NY, USA, 2013.

51. Innis, S.M. Palmitic Acid in Early Human Development. Crit. Rev. Food Sci. Nutr. 2016, 56, 1952-1959. [CrossRef] [PubMed]

52. Trinchese, G.; Cavaliere, G.; Canani, R.B.; Matamoros, S.; Bergamo, P.; De Filippo, C.; Aceto, S.; Gaita, M.; Cerino, P.; Negri, R.; et al. Human, donkey and cow milk differently affects energy efficiency and inflammatory state by modulating mitochondrial function and gut microbiota. J. Nutr. Biochem. 2015, 26, 1136-1146. [CrossRef] [PubMed]

53. Lionetti, L.; Cavaliere, G.; Bergamo, P.; Trinchese, G.; De Filippo, C.; Gifuni, G.; Gaita, M.; Pignalosa, A.; Donizzetti, I.; Putti, R.; et al. Diet supplementation with donkey milk upregulates liver mitochondrial uncoupling, reduces energy efficiency and improves antioxidant and antiinflammatory defences in rats. Mol. Nutr. Food Res. 2012, 56, 1596-1600. [CrossRef] [PubMed] 
54. Trinchese, G.; Cavaliere, G.; De Filippo, C.; Aceto, S.; Prisco, M.; Chun, J.T.; Penna, E.; Negri, R.; Muredda, L.; Demurtas, A.; et al. Human Milk and Donkey Milk, Compared to Cow Milk, Reduce Inflammatory Mediators and Modulate Glucose and Lipid Metabolism, Acting on Mitochondrial Function and Oleylethanolamide Levels in Rat Skeletal Muscle. Front. Physiol. 2018,9 , 32. [CrossRef] [PubMed]

55. Carta, G.; Murru, E.; Lisai, S.; Sirigu, A.; Piras, A.; Collu, M.; Batetta, B.; Gambelli, L.; Banni, S. Dietary triacylglycerols with palmitic acid in the sn-2 position modulate levels of $\mathrm{N}$-acylethanolamides in rat tissues. PLoS ONE 2015, 10, e0120424. [CrossRef]

56. Contreras, A.V.; Torres, N.; Tovar, A.R. PPAR- $\alpha$ as a key nutritional and environmental sensor for metabolic adaptation. Adv. Nutr. 2013, 4, 439-452. [CrossRef]

57. Pontis, S.; Ribeiro, A.; Sasso, O.; Piomelli, D. Macrophage-derived lipid agonists of PPAR- $\alpha$ as intrinsic controllers of inflammation. Crit. Rev. Biochem. Mol. Biol. 2016, 51, 7-14. [CrossRef] [PubMed]

58. Garwolińska, D.; Namieśnik, J.; Kot-Wasik, A.; Hewelt-Belka, W. Chemistry of Human Breast Milk-A Comprehensive Review of the Composition and Role of Milk Metabolites in Child Development. J. Agric. Food Chem. 2018, 66, 11881-11896. [CrossRef] [PubMed]

59. Innis, S.M. Impact of maternal diet on human milk composition and neurological development of infants. Am. J. Clin. Nutr. 2014, 99, 734S-741S. [CrossRef] [PubMed]

60. Ballard, O.; Morrow, A.L. Human milk composition: Nutrients and bioactive factors. Pediatr. Clin. N. Am. 2013, 60, 49-74. [CrossRef] [PubMed]

61. Paparo, L.; Nocerino, R.; Ciaglia, E.; Di Scala, C.; De Caro, C.; Russo, R.; Trinchese, G.; Aitoro, R.; Amoroso, A.; Bruno, C.; et al. Butyrate as bioactive human milk protective component against food allergy. Allergy 2020. [CrossRef]

62. Wagner, C.L.; Anderson, D.M.; Pittard, W.B. Special Properties of Human Milk. Clin. Pediatr. 1996, 35, 283-293. [CrossRef]

63. Schanler, R.J.; Atkinson, S.A. Effects of nutrients in human milk on the recipient premature infant. J. Mammary Gland. Biol. Neoplasia 1999, 4, 297-307. [CrossRef]

64. Alothman, M.; Hogan, S.A.; Hennessy, D.; Dillon, P.; Kilcawley, K.N.; O’Donovan, M.; Tobin, J.; Fenelon, M.A.; O'Callaghan, T.F. The "Grass-Fed" Milk Story: Understanding the Impact of Pasture Feeding on the Composition and Quality of Bovine Milk. Foods 2019, 8, 350. [CrossRef]

65. Verruck, S.; Dantas, A.; Prudencio, E.S. Functionality of the components from goat's milk, recent advances for functional dairy products development and its implications on human health. J. Funct. Foods 2019, 52, 243-257. [CrossRef]

66. Palupi, E.; Jayanegara, A.; Ploeger, A.; Kahl, J. Comparison of nutritional quality between conventional and organic dairy products: A meta-analysis. J. Sci. Food Agric. 2012, 92, 2774-2781. [CrossRef]

67. Schwendel, B.H.; Morel, P.C.; Wester, T.J.; Tavendale, M.H.; Deadman, C.; Fong, B.; Shadbolt, N.M.; Thatcher, A.; Otter, D.E. Fatty acid profile differs between organic and conventionally produced cow milk independent of season or milking time. J. Dairy Sci. 2015, 98, 1411-1425. [CrossRef]

68. Średnicka-Tober, D.; Barański, M.; Seal, C.J.; Sanderson, R.; Benbrook, C.; Steinshamn, H.; Gromadzka-Ostrowska, J.; Rembiałkowska, E.; Skwarło-Sońta, K.; Eyre, M.; et al. Higher PUFA and n-3 PUFA, conjugated linoleic acid, $\alpha$-tocopherol and iron, but lower iodine and selenium concentrations in organic milk: A systematic literature review and meta- and redundancy analyses. $\mathrm{Br}$. J. Nutr. 2016, 115, 1043-1060. [CrossRef] [PubMed]

69. Tsiplakou, E.; Kotrotsios, V.; Hadjigeorgiou, I.; Zervas, G. Differences in sheep and goats milk fatty acid profile between conventional and organic farming systems. J. Dairy Res. 2010, 77, 343-349. [CrossRef]

70. Tudisco, R.; Cutrignelli, M.I.; Calabrò, S.; Piccolo, G.; Bovera, F.; Guglielmelli, A.; Moniello, G.; Infascelli, F. Influence of organic systems on milk fatty acid profile and CLA in goats. Small Rumin. Res. 2010, 88, 151-155. [CrossRef]

71. Cabiddu, A.; Addis, M.; Spada, S.; Sitzia, M.; Molle, G.; Piredda, G. The Effect of Different Legume-Based Pastures on the Fatty Acid Composition of Sheep Milk with Focus on CLA; Zürich: Zürich, Switzerland, 2004; pp. 1133-1135.

72. Griinari, J.M.; Baumann, D.E. Biosynthesis of Conjugated Linoleic Acid and Its Incorporation into Meat and Milk in Ruminant; Yurawecz, M.P., Mossoba, M.M., Kramer, J.K.G., Pariza, M.W., Nelson, G.J., Eds.; Advances in Conjugated Linoleic Acid Research: Champaign, IL, USA, 1999; pp. 180-200.

73. Banni, S.; Carta, G.; Contini, M.S.; Angioni, E.; Deiana, M.; Dessì, M.A.; Melis, M.P.; Corongiu, F.P. Characterization of conjugated diene fatty acids in milk, dairy products, and lamb tissues. J. Nutr. Biochem. 1996, 7, 150-155. [CrossRef]

74. Dhiman, T.R.; Anand, G.R.; Satter, L.D.; Pariza, M.W. Conjugated linoleic acid content of milk from cows fed different diets. J. Dairy Sci. 1999, 82, 2146-2156. [CrossRef]

75. Bergamo, P.; Fedele, E.; Iannibelli, L.; Marzillo, G. Fat-soluble vitamin contents and fatty acid composition in organic and conventional Italian dairy products. Food Chem. 2003, 82, 625-631. [CrossRef]

76. Glover, K.E.; Budge, S.; Rose, M.; Rupasinghe, H.P.; Maclaren, L.; Green-Johnson, J.; Fredeen, A.H. Effect of feeding fresh forage and marine algae on the fatty acid composition and oxidation of milk and butter. J. Dairy Sci. 2012, 95, 2797-2809. [CrossRef]

77. Tudisco, R.; Calabrò, S.; Cutrignelli, M.; Moniello, G.; Grossi, M.; Gonzalez, O.; Piccolo, V.; Infascelli, F. Influence of organic systems on Stearoyl-CoA desaturase gene expression in goat milk. Small Rumin. Res. 2012, 106, S37-S42. [CrossRef]

78. Tudisco, R.; Grossi, M.; Calabrò, S.; Cutrignelli, M.I.; Musco, N.; Addi, L.; Infascelli, F. Influence of pasture on goat milk fatty acids and Stearoyl-CoA desaturase expression in milk somatic cells. Small Rumin. Res. 2014, 122, 38-43. [CrossRef]

79. Tsiplakou, E.; Mountzouris, K.; Zervas, G. Concentration of conjugated linoleic acid in grazing sheep and goat milk fat. Livest. Sci. 2006, 103, 74-84. [CrossRef] 
80. Nudda, A.; Cannas, A.; Correddu, F.; Atzori, A.S.; Lunesu, M.F.; Battacone, G.; Pulina, G. Sheep and Goats Respond Differently to Feeding Strategies Directed to Improve the Fatty Acid Profile of Milk Fat. Animals 2020, 10, 1290. [CrossRef]

81. Marcello, M.; Arianna, B.; Francesco, P.; Andrea, S.; Sebastiano, B.; Mauro, A.; Pierlorenzo, S. Effect of forage/concentrate ratio and soybean oil supplementation on milk yield, and composition from Sarda ewes. Anim. Res. 2006, 55, $273-285$.

82. Kim, Y.J.; Liu, R.H.; Bond, D.R.; Russell, J.B. Effect of linoleic acid concentration on conjugated linoleic acid production by Butyrivibrio fibrisolvens A38. Appl. Environ. Microbiol. 2000, 66, 5226-5230. [CrossRef]

83. Aii, T.; Takahashi, S.; Kurihara, M.; Kune, S. The effects of Italian rye grass hay, haylage and fresh Italian Rye grass on the fatty acid composition of cow's milk. Jpn. J. Zootech. Sci. 1988, 59, 718-724.

84. Dewhurst, R.; Shingfield, K.; Lee, M.; Scollan, N. Increasing the concentrations of beneficial polyunsaturated fatty acids in milk produced by dairy cows in high-forage systems. Anim. Feed. Sci. Technol. 2006, 131, 168-206. [CrossRef]

85. Benbrook, C.M.; Davis, D.R.; Heins, B.J.; Latif, M.A.; Leifert, C.; Peterman, L.; Butler, G.; Faergeman, O.; Abel-Caines, S.; Baranski, M. Enhancing the fatty acid profile of milk through forage-based rations, with nutrition modeling of diet outcomes. Food Sci. Nutr. 2018, 6, 681-700. [CrossRef] [PubMed]

86. Davis, H.; Chatzidimitriou, E.; Leifert, C.; Butler, G. Evidence That Forage-Fed Cows Can Enhance Milk Quality. Sustainability 2020, 12, 3688. [CrossRef]

87. Bisig, W.; Eberhard, P.; Collomb, M.; Rehberger, B. Influence of processing on the fatty acid composition and the content of conjugated linoleic acid in organic and conventional dairy products-A review. Le Lait 2007, 87, 1-19. [CrossRef]

88. Prandini, A.; Sigolo, S.; Piva, G. A comparative study of fatty acid composition and CLA concentration in commercial cheeses. J. Food Compos. Anal. 2011, 24, 55-61. [CrossRef]

89. Ellis, K.A.; Innocent, G.; Grove-White, D.; Cripps, P.; McLean, W.G.; Howard, C.V.; Mihm, M. Comparing the fatty acid composition of organic and conventional milk. J. Dairy Sci. 2006, 89, 1938-1950. [CrossRef]

90. Lourenço, M.; Van Ranst, G.; Vlaeminck, B.; De Smet, S.; Fievez, V. Influence of different dietary forages on the fatty acid composition of rumen digesta as well as ruminant meat and milk. Anim. Feed. Sci. Technol. 2008, 145, 418-437. [CrossRef]

91. Uzun, P.; Masucci, F.; Serrapica, F.; Napolitano, F.; Braghieri, A.; Romano, R.; Manzo, N.; Esposito, G.; Di Francia, A. The inclusion of fresh forage in the lactating buffalo diet affects fatty acid and sensory profile of mozzarella cheese. J. Dairy Sci. 2018, 101, 6752-6761. [CrossRef]

92. Wongtangtintharn, S.; Oku, H.; Iwasaki, H.; Toda, T. Effect of branched-chain fatty acids on fatty acid biosynthesis of human breast cancer cells. J. Nutr. Sci. Vitaminol. 2004, 50, 137-143. [CrossRef]

93. Ran-Ressler, R.R.; Khailova, L.; Arganbright, K.M.; Adkins-Rieck, C.K.; Jouni, Z.E.; Koren, O.; Ley, R.E.; Brenna, J.T.; Dvorak, B. Branched chain fatty acids reduce the incidence of necrotizing enterocolitis and alter gastrointestinal microbial ecology in a neonatal rat model. PLoS ONE 2011, 6, e29032. [CrossRef] [PubMed]

94. Kraft, J.; Jetton, T.; Satish, B.; Gupta, D. Dairy-derived bioactive fatty acids improve pancreatic ß-cell function. FASEB J. 2015, 29, 608-625. [CrossRef]

95. Forouhi, N.G.; Koulman, A.; Sharp, S.J.; Imamura, F.; Kröger, J.; Schulze, M.B.; Crowe, F.L.; Huerta, J.M.; Guevara, M.; Beulens, J.W.; et al. Differences in the prospective association between individual plasma phospholipid saturated fatty acids and incident type 2 diabetes: The EPIC-InterAct case-cohort study. Lancet Diabetes Endocrinol. 2014, 2, 810-818. [CrossRef]

96. Sun, Q.; Ma, J.; Campos, H.; Hu, F.B. Plasma and erythrocyte biomarkers of dairy fat intake and risk of ischemic heart disease Am. J. Clin. Nutr. 2007, 86, 929-937. [CrossRef] [PubMed]

97. Khaw, K.-T.; Friesen, M.D.; Riboli, E.; Luben, R.; Wareham, N. Plasma Phospholipid Fatty Acid Concentration and Incident Coronary Heart Disease in Men and Women: The EPIC-Norfolk Prospective Study. PLoS Med. 2012, 9, e1001255. [CrossRef]

98. Vlaeminck, B.; Fievez, V.; Cabrita, A.; Fonseca, A.; Dewhurst, R. Factors affecting odd- and branched-chain fatty acids in milk: A review. Anim. Feed. Sci. Technol. 2006, 131, 389-417. [CrossRef]

99. Massart-Leën, A.; Roets, E.; Peeters, G.; Verbeke, R. Propionate for Fatty Acid Synthesis by the Mammary Gland of the Lactating Goat. J. Dairy Sci. 1983, 66, 1445-1454. [CrossRef]

100. Alonso, L.; Fontecha, J.; Lozada, L.; Fraga, M.J.; Juárez, M. Fatty acid composition of caprine milk: Major, branched-chain, and trans fatty acids. J. Dairy Sci. 1999, 82, 878-884. [CrossRef]

101. Bainbridge, M.L.; Cersosimo, L.M.; Wright, A.D.; Kraft, J. Content and Composition of Branched-Chain Fatty Acids in Bovine Milk Are Affected by Lactation Stage and Breed of Dairy Cow. PLoS ONE 2016, 11, e0150386. [CrossRef] [PubMed]

102. Craninx, M.; Steen, A.; Van Laar, H.; Van Nespen, T.; Martín-Tereso, J.; De Baets, B.; Fievez, V. Effect of lactation stage on the odd- and branched-chain milk fatty acids of dairy cattle under grazing and indoor conditions. J. Dairy Sci. 2008, 91, 2662-2677. [CrossRef]

103. Lopez, A.; Vasconi, M.; Moretti, V.M.; Bellagamba, F. Fatty Acid Profile in Goat Milk from High- and Low-Input Conventional and Organic Systems. Animals 2019, 9, 452. [CrossRef] [PubMed]

104. Mele, M.; Serra, A.; Buccioni, A.; Conte, G.; Pollicardo, A.; Secchiari, P. Effect of soybean oil supplementation on milk fatty acid composition from Saanen goats fed diets with different forage:concentrate ratios. Ital. J. Anim. Sci. 2008, 7, 297-311. [CrossRef]

105. Serment, A.; Schmidely, P.; Giger-Reverdin, S.; Chapoutot, P.; Sauvant, D. Effects of the percentage of concentrate on rumen fermentation, nutrient digestibility, plasma metabolites, and milk composition in mid-lactation goats. J. Dairy Sci. 2011, 94, 3960-3972. [CrossRef] [PubMed] 
106. Martínez Marín, A.L.; Gómez-Cortés, P.; Gómez Castro, A.G.; Juárez, M.; Pérez Alba, L.M.; Pérez Hernández, M.; de la Fuente, M.A. Animal performance and milk fatty acid profile of dairy goats fed diets with different unsaturated plant oils. J. Dairy Sci. 2011, 94, 5359-5368. [CrossRef] [PubMed]

107. Falchero, L.; Lombardi, G.; Gorlier, A.; Lonati, M.; Odoardi, M.; Cavallero, A. Variation in fatty acid composition of milk and cheese from cows grazed on two alpine pastures. Dairy Sci. Technol. 2010, 90, 657-672. [CrossRef]

108. Gabbs, M.; Leng, S.; Devassy, J.G.; Monirujjaman, M.; Aukema, H.M. Advances in Our Understanding of Oxylipins Derived from Dietary PUFAs. Adv. Nutr. 2015, 6, 513-540. [CrossRef]

109. Nguyen, Q.V.; Malau-Aduli, B.S.; Cavalieri, J.; Malau-Aduli, A.E.O.; Nichols, P.D. Enhancing Omega-3 Long-Chain Polyunsaturated Fatty Acid Content of Dairy-Derived Foods for Human Consumption. Nutrients 2019, 11, 743. [CrossRef] [PubMed]

110. Sanders, T.A.; Gleason, K.; Griffin, B.; Miller, G.J. Influence of an algal triacylglycerol containing docosahexaenoic acid (22: 6n-3) and docosapentaenoic acid (22: 5n-6) on cardiovascular risk factors in healthy men and women. Br. J. Nutr. 2006, 95, 525-531. [CrossRef]

111. Hardman, W.E. Omega-3 fatty acids to augment cancer therapy. J. Nutr. 2002, 132, 3508S-3512S. [CrossRef] [PubMed]

112. Xue, B.; Yang, Z.; Wang, X.; Shi, H. Omega-3 polyunsaturated fatty acids antagonize macrophage inflammation via activation of AMPK/SIRT1 pathway. PLoS ONE 2012, 7, e45990. [CrossRef]

113. Martínez-Fernández, L.; Laiglesia, L.M.; Huerta, A.E.; Martínez, J.A.; Moreno-Aliaga, M.J. Omega-3 fatty acids and adipose tissue function in obesity and metabolic syndrome. Prostaglandins Other Lipid Mediat. 2015, 121, 24-41. [CrossRef] [PubMed]

114. Lionetti, L.; Mollica, M.P.; Donizzetti, I.; Gifuni, G.; Sica, R.; Pignalosa, A.; Cavaliere, G.; Gaita, M.; De Filippo, C.; Zorzano, A.; et al. High-lard and high-fish-oil diets differ in their effects on function and dynamic behaviour of rat hepatic mitochondria. PLoS ONE 2014, 9, e92753. [CrossRef]

115. Cavaliere, G.; Trinchese, G.; Bergamo, P.; De Filippo, C.; Mattace Raso, G.; Gifuni, G.; Putti, R.; Moni, B.H.; Canani, R.B.; Meli, R.; et al. Polyunsaturated Fatty Acids Attenuate Diet Induced Obesity and Insulin Resistance, Modulating Mitochondrial Respiratory Uncoupling in Rat Skeletal Muscle. PLoS ONE 2016, 11, e0149033. [CrossRef]

116. Kim, J.H.; Kim, Y.; Kim, Y.J.; Park, Y. Conjugated Linoleic Acid: Potential Health Benefits as a Functional Food Ingredient. Annu. Rev. Food Sci. Technol. 2016, 7, 221-244. [CrossRef]

117. Yang, B.; Chen, H.; Stanton, C.; Ross, R.P.; Zhang, H.; Chen, Y.Q.; Chen, W. Review of the roles of conjugated linoleic acid in health and disease. J. Funct. Foods 2015, 15, 314-325. [CrossRef]

118. Risérus, U.; Basu, S.; Jovinge, S.; Fredrikson, G.N.; Arnlöv, J.; Vessby, B. Supplementation with conjugated linoleic acid causes isomer-dependent oxidative stress and elevated C-reactive protein: A potential link to fatty acid-induced insulin resistance. Circulation 2002, 106, 1925-1929. [CrossRef]

119. Moloney, F.; Toomey, S.; Noone, E.; Nugent, A.; Allan, B.; Loscher, C.E.; Roche, H.M. Antidiabetic effects of cis-9, trans-11conjugated linoleic acid may be mediated via anti-inflammatory effects in white adipose tissue. Diabetes 2007, 56, 574-582. [CrossRef]

120. Choi, J.S.; Koh, I.U.; Jung, M.H.; Song, J. Effects of three different conjugated linoleic acid preparations on insulin signalling, fat oxidation and mitochondrial function in rats fed a high-fat diet. Br. J. Nutr. 2007, 98, 264-275. [CrossRef]

121. Castro-Webb, N.; Ruiz-Narváez, E.A.; Campos, H. Cross-sectional study of conjugated linoleic acid in adipose tissue and risk of diabetes. Am. J. Clin. Nutr. 2012, 96, 175-181. [CrossRef]

122. Viladomiu, M.; Hontecillas, R.; Bassaganya-Riera, J. Modulation of inflammation and immunity by dietary conjugated linoleic acid. Eur. J. Pharmacol. 2016, 785, 87-95. [CrossRef]

123. Motohashi, H.; Yamamoto, M. Nrf2-Keap1 defines a physiologically important stress response mechanism. Trends Mol. Med. 2004, 10, 549-557. [CrossRef] [PubMed]

124. Mollica, M.P.; Trinchese, G.; Cavaliere, G.; De Filippo, C.; Cocca, E.; Gaita, M.; Della-Gatta, A.; Marano, A.; Mazzarella, G.; Bergamo, P. c9,t11-Conjugated linoleic acid ameliorates steatosis by modulating mitochondrial uncoupling and Nrf2 pathway. J. Lipid Res. 2014, 55, 837-849. [CrossRef] [PubMed]

125. Bergamo, P.; Palmieri, G.; Cocca, E.; Ferrandino, I.; Gogliettino, M.; Monaco, A.; Maurano, F.; Rossi, M. Adaptive response activated by dietary cis9, trans11 conjugated linoleic acid prevents distinct signs of gliadin-induced enteropathy in mice. Eur. J. Nutr. 2016, 55, 729-740. [CrossRef] [PubMed]

126. Piras, A.; Carta, G.; Murru, E.; Lopes, P.A.; Martins, S.V.; Prates, J.A.; Banni, S. Effects of dietary CLA on n-3 HUFA score and $\mathrm{N}$-acylethanolamides biosynthesis in the liver of obese Zucker rats. Prostaglandins Leukot. Essent. Fat. Acids 2015, 98, 15-19. [CrossRef] [PubMed]

127. Murru, E.; Carta, G.; Cordeddu, L.; Melis, M.P.; Desogus, E.; Ansar, H.; Chilliard, Y.; Ferlay, A.; Stanton, C.; Coakley, M.; et al. Dietary Conjugated Linoleic Acid-Enriched Cheeses Influence the Levels of Circulating n-3 Highly Unsaturated Fatty Acids in Humans. Int. J. Mol. Sci. 2018, 19, 1730. [CrossRef]

128. Trinchese, G.; Cavaliere, G.; Penna, E.; De Filippo, C.; Cimmino, F.; Catapano, A.; Musco, N.; Tudisco, R.; Lombardi, P.; Infascelli, F.; et al. Milk From Cow Fed With High Forage/Concentrate Ratio Diet: Beneficial Effect on Rat Skeletal Muscle Inflammatory State and Oxidative Stress Through Modulation of Mitochondrial Functions and AMPK Activity. Front. Physiol. 2019, 9. [CrossRef]

129. Mollica, M.P.; Lionetti, L.; Moreno, M.; Lombardi, A.; De Lange, P.; Antonelli, A.; Lanni, A.; Cavaliere, G.; Barletta, A.; Goglia, F. 3,5-diiodo-l-thyronine, by modulating mitochondrial functions, reverses hepatic fat accumulation in rats fed a high-fat diet. $J$. Hepatol. 2009, 51, 363-370. [CrossRef] [PubMed] 
130. Trinchese, G.; Cavaliere, G.; Cimmino, F.; Catapano, A.; Carta, G.; Pirozzi, C.; Murru, E.; Lama, A.; Meli, R.; Bergamo, P.; et al. Decreased Metabolic Flexibility in Skeletal Muscle of Rat Fed with a High-Fat Diet Is Recovered by Individual CLA Isomer Supplementation via Converging Protective Mechanisms. Cells 2020, 9, 823. [CrossRef] [PubMed]

131. Benoit, B.; Plaisancié, P.; Géloën, A.; Estienne, M.; Debard, C.; Meugnier, E.; Loizon, E.; Daira, P.; Bodennec, J.; Cousin, O.; et al. Pasture v. standard dairy cream in high-fat diet-fed mice: Improved metabolic outcomes and stronger intestinal barrier. $\mathrm{Br}$. $\mathrm{J}$. Nutr. 2014, 112, 520-535. [CrossRef] [PubMed]

132. Bergamo, P.; Maurano, F.; Rossi, M. Phase 2 enzyme induction by conjugated linoleic acid improves lupus-associated oxidative stress. Free Radic. Biol. Med. 2007, 43, 71-79. [CrossRef]

133. Benjamin, S.; Spener, F. Conjugated linoleic acids as functional food: An insight into their health benefits. Nutr. Metab. 2009, 6, 36. [CrossRef] [PubMed]

134. Pintus, S.; Murru, E.; Carta, G.; Cordeddu, L.; Batetta, B.; Accossu, S.; Pistis, D.; Uda, S.; Elena Ghiani, M.; Mele, M.; et al. Sheep cheese naturally enriched in $\alpha$-linolenic, conjugated linoleic and vaccenic acids improves the lipid profile and reduces anandamide in the plasma of hypercholesterolaemic subjects. Br. J. Nutr. 2013, 109, 1453-1462. [CrossRef]

135. Santurino, C.; López-Plaza, B.; Fontecha, J.; Calvo, M.V.; Bermejo, L.M.; Gómez-Andrés, D.; Gómez-Candela, C. Consumption of Goat Cheese Naturally Rich in Omega-3 and Conjugated Linoleic Acid Improves the Cardiovascular and Inflammatory Biomarkers of Overweight and Obese Subjects: A Randomized Controlled Trial. Nutrients 2020, 12, 1315. [CrossRef]

136. Costa, A.; Lopez-Villalobos, N.; Sneddon, N.; Shalloo, L.; Franzoi, M.; De Marchi, M.; Penasa, M. Invited review: Milk lactoseCurrent status and future challenges in dairy cattle. J. Dairy Sci. 2019, 102, 5883-5898. [CrossRef]

137. Lock, A.L.; Bauman, D.E. Modifying milk fat composition of dairy cows to enhance fatty acids beneficial to human health. Lipids 2004, 39, 1197-1206. [CrossRef]

138. Mele, M.C.; Cannelli, G.; Carta, G.; Cordeddu, L.; Melis, M.P.; Murru, E.; Stanton, C.; Banni, S. Metabolism of c9,t11-conjugated linoleic acid (CLA) in humans. Prostaglandins Leukot. Essent. Fatty Acids 2013, 89, 115-119. [CrossRef]

139. Rist, L.; Mueller, A.; Barthel, C.; Snijders, B.; Jansen, M.; Simões-Wüst, A.P.; Huber, M.; Kummeling, I.; von Mandach, U.; Steinhart, $\mathrm{H}$; ; et al. Influence of organic diet on the amount of conjugated linoleic acids in breast milk of lactating women in the Netherlands. Br. J. Nutr. 2007, 97, 735-743. [CrossRef]

140. Aro, A.; Männistö, S.; Salminen, I.; Ovaskainen, M.L.; Kataja, V.; Uusitupa, M. Inverse association between dietary and serum conjugated linoleic acid and risk of breast cancer in postmenopausal women. Nutr. Cancer. 2000, 38, 151-157. [CrossRef] [PubMed]

141. McCann, S.E.; Ip, C.; Ip, M.M.; McGuire, M.K.; Muti, P.; Edge, S.B.; Trevisan, M.; Freudenheim, J.L. Dietary intake of conjugated linoleic acids and risk of premenopausal and postmenopausal breast cancer, Western New York Exposures and Breast Cancer Study (WEB Study). Cancer Epidemiol. Biomark. Prev. 2004, 13, 1480-1484.

142. Haug, A.; Sjøgren, P.; Hølland, N.; Müller, H.; Kjos, N.P.; Taugbøl, O.; Fjerdingby, N.; Biong, A.S.; Selmer-Olsen, E.; Harstad, O.M. Effects of butter naturally enriched with conjugated linoleic acid and vaccenic acid on blood lipids and LDL particle size in growing pigs. Lipids Health Dis. 2008, 7, 31. [CrossRef] [PubMed]

143. Chinnadurai, K.; Kanwal, H.K.; Tyagi, A.K.; Stanton, C.; Ross, P. High conjugated linoleic acid enriched ghee (clarified butter) increases the antioxidant and antiatherogenic potency in female Wistar rats. Lipids Health Dis. 2013, 12, 121. [CrossRef] [PubMed]

144. De Almeida, M.M.; Luquetti, S.C.P.D.; Sabarense, C.M.; Corrêa, J.O.D.A.; Dos Reis, L.G.; Da Conceição, E.P.S.; Lisboa, P.C.; De Moura, E.G.; Gameiro, J.; Da Gama, M.A.S.; et al. Butter naturally enriched in cis-9, trans-11 CLA prevents hyperinsulinemia and increases both serum HDL cholesterol and triacylglycerol levels in rats. Lipids Health Dis. 2014, 13, 200. [CrossRef]

145. Gama, M.A.S.; Raposo, N.R.B.; Mury, F.B.; Lopes, F.C.F.; Dias-Neto, E.; Talib, L.L.; Gattaz, W.F. Conjugated linoleic acid-enriched butter improved memory and up-regulated phospholipase A2 encoding-genes in rat brain tissue. J. Neural Transm. 2015, 122, 1371-1380. [CrossRef]

146. Bergamo, P.; Cocca, E.; Monaco, A.; Cozzolino, V.; Boscaino, F.; Ferrandino, I.; Maurano, F.; Rossi, M. Protective effect of Rumenic acid rich cow's milk against colitis is associated with the activation of Nrf2 pathway in a murine model. Prostaglandins Leukot. Essent. Fatty Acids 2017, 125, 14-23. [CrossRef] [PubMed]

147. Tricon, S.; Burdge, G.C.; Kew, S.; Banerjee, T.; Russell, J.J.; Jones, E.L.; Grimble, R.F.; Williams, C.M.; Yaqoob, P.; Calder, P.C. Opposing effects of cis-9,trans-11 and trans-10,cis-12 conjugated linoleic acid on blood lipids in healthy humans. Am. J. Clin. Nutr. 2004, 80, 614-620. [CrossRef]

148. Sofi, F.; Buccioni, A.; Cesari, F.; Gori, A.M.; Minieri, S.; Mannini, L.; Casini, A.; Gensini, G.F.; Abbate, R.; Antongiovanni, M. Effects of a dairy product (pecorino cheese) naturally rich in cis-9, trans-11 conjugated linoleic acid on lipid, inflammatory and haemorheological variables: A dietary intervention study. Nutr Metab Cardiovasc. Dis. 2010, 20, 117-124. [CrossRef]

149. Penedo, L.A.; Nunes, J.C.; Gama, M.A.; Leite, P.E.; Quirico-Santos, T.F.; Torres, A.G. Intake of butter naturally enriched with cis 9 , trans 11 conjugated linoleic acid reduces systemic inflammatory mediators in healthy young adults. J. Nutr. Biochem. 2013, 24, 2144-2151. [CrossRef]

150. Derakhshande-Rishehri, S.M.; Mansourian, M.; Kelishadi, R.; Heidari-Beni, M. Association of foods enriched in conjugated linoleic acid (CLA) and CLA supplements with lipid profile in human studies: A systematic review and meta-analysis. Public Health Nutr. 2015, 18, 2041-2054. [CrossRef] [PubMed]

151. Steiner, P. Brain Fuel Utilization in the Developing Brain. Ann. Nutr. Metab. 2019, 75, 8-18. [CrossRef] 
152. Goyal, M.S.; Iannotti, L.L.; Raichle, M.E. Brain Nutrition: A Life Span Approach. Annu. Rev. Nutr. 2018, 38, 381-399. [CrossRef] [PubMed]

153. Godos, J.; Currenti, W.; Angelino, D.; Mena, P.; Castellano, S.; Caraci, F.; Galvano, F.; Del Rio, D.; Ferri, R.; Grosso, G. Diet and Mental Health: Review of the Recent Updates on Molecular Mechanisms. Antioxidants 2020, 9, 346. [CrossRef] [PubMed]

154. Baranowski, B.J.; Marko, D.M.; Fenech, R.K.; Yang, A.J.T.; MacPherson, R.E.K. Healthy brain, healthy life: A review of diet and exercise interventions to promote brain health and reduce Alzheimer's disease risk. Appl. Physiol. Nutr. Metab. 2020, 45, 1055-1065. [CrossRef] [PubMed]

155. Yonezawa, K.; Kusumoto, Y.; Kanchi, N.; Kinoshita, H.; Kanegae, S.; Yamaguchi, N.; Ozawa, H. Recent trends in mental illness and omega-3 fatty acids. J. Neural Transm. 2020, 127, 1491-1499. [CrossRef]

156. Matura, S.; Prvulovic, D.; Mohadjer, N.; Fusser, F.; Oertel, V.; Reif, A.; Pantel, J.; Karakaya, T. Association of dietary fat composition with cognitive performance and brain morphology in cognitively healthy individuals. Acta Neuropsychiatr. 2021, 1-7. [CrossRef]

157. Alessandri, J.M.; Guesnet, P.; Vancassel, S.; Astorg, P.; Denis, I.; Langelier, B.; Aïd, S.; Poumès-Ballihaut, C.; Champeil-Potokar, G.; Lavialle, M. Polyunsaturated fatty acids in the central nervous system: Evolution of concepts and nutritional implications throughout life. Reprod. Nutr. Dev. 2004, 44, 509-538. [CrossRef]

158. Gómez-Pinilla, F. Brain foods: The effects of nutrients on brain function. Nat. Rev. Neurosci. 2008, 9, 568-578. [CrossRef]

159. Eckert, G.P.; Lipka, U.; Muller, W.E. Omega-3 fatty acids in neurodegenerative diseases: Focus on mitochondria. Prostaglandins Leukot. Essent. Fatty Acids 2013, 88, 105-114. [CrossRef]

160. Martin, C.R.; Ling, P.R.; Blackburn, G.L. Review of Infant Feeding: Key Features of Breast Milk and Infant Formula. Nutrients 2016, 8, 279. [CrossRef] [PubMed]

161. Tyagi, E.; Agrawal, R.; Zhuang, Y.; Abad, C.; Waschek, J.A.; Gomez-Pinilla, F. Vulnerability imposed by diet and brain trauma for anxiety-like phenotype: Implications for post-traumatic stress disorders. PLoS ONE 2013, 8, e57945. [CrossRef] [PubMed]

162. Su, K.P.; Lai, H.C.; Yang, H.T.; Su, W.P.; Peng, C.Y.; Chang, J.P.; Chang, H.C.; Pariante, C.M. Omega-3 fatty acids in the prevention of interferon-alpha-induced depression: Results from a randomized, controlled trial. Biol. Psychiatry 2014, 76, 559-566. [CrossRef] [PubMed]

163. Hashimoto, K. Brain-derived neurotrophic factor as a biomarker for mood disorders: An historical overview and future directions. Psychiatry Clin. Neurosci. 2010, 64, 341-357. [CrossRef]

164. Wu, A.; Ying, Z.; Gomez-Pinilla, F. The interplay between oxidative stress and brain-derived neurotrophic factor modulates the outcome of a saturated fat diet on synaptic plasticity and cognition. Eur. J. Neurosci. 2004, 19, 1699-1707. [CrossRef]

165. Blondeau, N.; Nguemeni, C.; Debruyne, D.N.; Piens, M.; Wu, X.; Pan, H.; Hu, X.; Gandin, C.; Lipsky, R.H.; Plumier, J.C.; et al. Subchronic alpha-linolenic acid treatment enhances brain plasticity and exerts an antidepressant effect: A versatile potential therapy for stroke. Neuropsychopharmacology 2009, 34, 2548-2559. [CrossRef]

166. Venna, V.R.; Deplanque, D.; Allet, C.; Belarbi, K.; Hamdane, M.; Bordet, R. PUFA induce antidepressant-like effects in parallel to structural and molecular changes in the hippocampus. Psychoneuroendocrinology 2009, 34, 199-211. [CrossRef]

167. Gomez-Pinilla, F.; Tyagi, E. Diet and cognition: Interplay between cell metabolism and neuronal plasticity. Curr. Opin. Clin. Nutr. Metab. Care 2013, 16, 726-733. [CrossRef]

168. Di Miceli, M.; Bosch-Bouju, C.; Layé, S. PUFA and their derivatives in neurotransmission and synapses: A new hallmark of synaptopathies. Proc. Nutr Soc. 2020, 1-16. [CrossRef] [PubMed]

169. Cefaliello, C.; Penna, E.; Barbato, C.; Di Ruberto, G.; Mollica, M.P.; Trinchese, G.; Cigliano, L.; Borsello, T.; Chun, J.T.; Giuditta, A.; et al. Deregulated Local Protein Synthesis in the Brain Synaptosomes of a Mouse Model for Alzheimer's Disease. Mol. Neurobiol. 2020, 57, 1529-1541. [CrossRef]

170. Eyman, M.; Cefaliello, C.; Mandile, P.; Piscopo, S.; Crispino, M.; Giuditta, A. Training old rats selectively modulates synaptosomal protein synthesis. J. Neurosci Res. 2013, 91, 20-29. [CrossRef]

171. Crispino, M.; Chun, J.T.; Cefaliello, C.; Perrone Capano, C.; Giuditta, A. Local gene expression in nerve endings. Dev. Neurobiol 2014, 74, 279-291. [CrossRef]

172. Crispino, M.; Cefaliello, C.; Kaplan, B.; Giuditta, A. Protein synthesis in nerve terminals and the glia-neuron unit. Results Probl. Cell. Differ. 2009, 48, 243-267. [CrossRef] [PubMed]

173. Chao, O.Y.; Marron Fernandez de Velasco, E.; Pathak, S.S.; Maitra, S.; Zhang, H.; Duvick, L.; Wickman, K.; Orr, H.T.; Hirai, H.; Yang, Y.M. Targeting inhibitory cerebellar circuitry to alleviate behavioral deficits in a mouse model for studying idiopathic autism. Neuropsychopharmacology 2020, 45, 1159-1170. [CrossRef]

174. Noseworthy, M.D.; Bray, T.M. Effect of oxidative stress on brain damage detected by MRI and in vivo 31P-NMR. Free Radic. Biol. Med. 1998, 24, 942-951. [CrossRef]

175. Farooqui, A.A.; Horrocks, L.A. Lipid peroxides in the free radical pathophysiology of brain diseases. Cell Mol. Neurobiol. 1998, 18, 599-608. [CrossRef] [PubMed]

176. Suzuki, H.; Manabe, S.; Wada, O.; Crawford, M.A. Rapid incorporation of docosahexaenoic acid from dietary sources into brain microsomal, synaptosomal and mitochondrial membranes in adult mice. Int. J. Vitam. Nutr. Res. 1997, 67, 272-278. [PubMed]

177. Brenna, J.T.; Diau, G.Y. The influence of dietary docosahexaenoic acid and arachidonic acid on central nervous system polyunsaturated fatty acid composition. Prostaglandins Leukot. Essent. Fatty Acids 2007, 77, 247-250. [CrossRef] [PubMed] 
178. Crispino, M.; Trinchese, G.; Penna, E.; Cimmino, F.; Catapano, A.; Villano, I.; Perrone-Capano, C.; Mollica, M.P. Interplay between Peripheral and Central Inflammation in Obesity-Promoted Disorders: The Impact on Synaptic Mitochondrial Functions. Int. J. Mol. Sci. 2020, 21, 5964. [CrossRef] [PubMed]

179. De Mello, A.H.; Schraiber, R.D.B.; Goldim, M.P.D.S.; Garcez, M.L.; Gomes, M.L.; Silveira, G.D.B.; Zaccaron, R.P.; Schuck, P.F.; Budni, J.; Silveira, P.C.L.; et al. Omega-3 Fatty Acids Attenuate Brain Alterations in High-Fat Diet-Induced Obesity Model. Mol. Neurobiol. 2019, 56, 513-524. [CrossRef]

180. Fà, M.; Diana, A.; Carta, G.; Cordeddu, L.; Melis, M.P.; Murru, E.; Sogos, V.; Banni, S. Incorporation and metabolism of c9,t11 and t10,c12 conjugated linoleic acid (CLA) isomers in rat brain. Biochim. Biophys. Acta (BBA) Mol. Cell Biol. Lipids 2005, 1736, 61-66. [CrossRef]

181. Soares, J.K.; Rocha-De-Melo, A.P.; Medeiros, M.C.; Queiroga, R.C.; Bomfim, M.A.; De Souza, A.F.; Nascimento, A.L.; Guedes, R.C. Conjugated linoleic acid in the maternal diet differentially enhances growth and cortical spreading depression in the rat progeny. Biochim. Biophys. Acta (BBA) Gen. Subj. 2012, 1820, 1490-1495. [CrossRef]

182. Murru, E.; Carta, G.; Manca, C.; Sogos, V.; Pistis, M.; Melis, M.; Banni, S. Conjugated Linoleic Acid and Brain Metabolism: A Possible Anti-Neuroinflammatory Role Mediated by PPAR $\alpha$ Activation. Front. Pharmacol. 2021, 11, 587140. [CrossRef]

183. Ho, W.S.; Barrett, D.A.; Randall, M.D. ‘Entourage' effects of N-palmitoylethanolamide and N-oleoylethanolamide on vasorelaxation to anandamide occur through TRPV1 receptors. Br. J. Pharmacol. 2008, 155, 837-846. [CrossRef] [PubMed]

184. Im, D.S. GPR119 and GPR55 as Receptors for Fatty Acid Ethanolamides, Oleoylethanolamide and Palmitoylethanolamide. Int. J. Mol. Sci. 2021, 22, 1034. [CrossRef] [PubMed]

185. Ambrosino, P.; Soldovieri, M.V.; Russo, C.; Taglialatela, M. Activation and desensitization of TRPV1 channels in sensory neurons by the PPAR $\alpha$ agonist palmitoylethanolamide. Br. J. Pharmacol. 2013, 168, 1430-1444. [CrossRef]

186. Saba, F.; Sirigu, A.; Pillai, R.; Caria, P.; Cordeddu, L.; Carta, G.; Murru, E.; Sogos, V.; Banni, S. Downregulation of inflammatory markers by conjugated linoleic acid isomers in human cultured astrocytes. Nutr. Neurosci. 2019, 22, 207-214. [CrossRef]

187. Nakanishi, T.; Koutoku, T.; Kawahara, S.; Murai, A.; Furuse, M. Dietary conjugated linoleic acid reduces cerebral prostaglandin E(2) in mice. Neurosci. Lett. 2003, 341, 135-138. [CrossRef]

188. Sikorski, A.M.; Hebert, N.; Swain, R.A. Conjugated Linoleic Acid (CLA) inhibits new vessel growth in the mammalian brain. Brain Res. 2008, 1213, 35-40. [CrossRef] [PubMed]

189. Tsuyama, S.; Oikawa, D.; Tsuji, Y.; Akimoto, Y.; Jikuya, H.; Furuse, M. Dietary conjugated linoleic acid modifies the brain endocannabinoid system in mice. Nutr. Neurosci. 2009, 12, 155-159. [CrossRef]

190. Monaco, A.; Ferrandino, I.; Boscaino, F.; Cocca, E.; Cigliano, L.; Maurano, F.; Luongo, D.; Spagnuolo, M.S.; Rossi, M.; Bergamo, P. Conjugated linoleic acid prevents age-dependent neurodegeneration in a mouse model of neuropsychiatric lupus via the activation of an adaptive response. J. Lipid Res. 2018, 59, 48-57. [CrossRef] [PubMed]

191. Cigliano, L.; Spagnuolo, M.S.; Boscaino, F.; Ferrandino, I.; Monaco, A.; Capriello, T.; Cocca, E.; Iannotta, L.; Treppiccione, L.; Luongo, D.; et al. Dietary Supplementation with Fish Oil or Conjugated Linoleic Acid Relieves Depression Markers in Mice by Modulation of the Nrf2 Pathway. Mol. Nutr. Food Res. 2019, 63, e1900243. [CrossRef] [PubMed]

192. Hunt, W.T.; Kamboj, A.; Anderson, H.D.; Anderson, C.M. Protection of cortical neurons from excitotoxicity by conjugated linoleic acid. J. Neurochem 2010, 115, 123-130. [CrossRef] [PubMed]

193. Queiroz, M.P.; Lima, M.D.S.; Barbosa, M.Q.; De Melo, M.F.F.T.; Bertozzo, C.C.D.M.S.; De Oliveira, M.E.G.; Bessa, R.J.B.; Alves, S.P.A.; Souza, M.I.A.; Queiroga, R.D.C.R.D.E.; et al. Effect of Conjugated Linoleic Acid on Memory and Reflex Maturation in Rats Treated During Early Life. Front. Neurosci. 2019, 13, 370. [CrossRef] [PubMed] 